Historic, archived document

Do not assume content reflects current scientific knowledge, policies, or practices. 


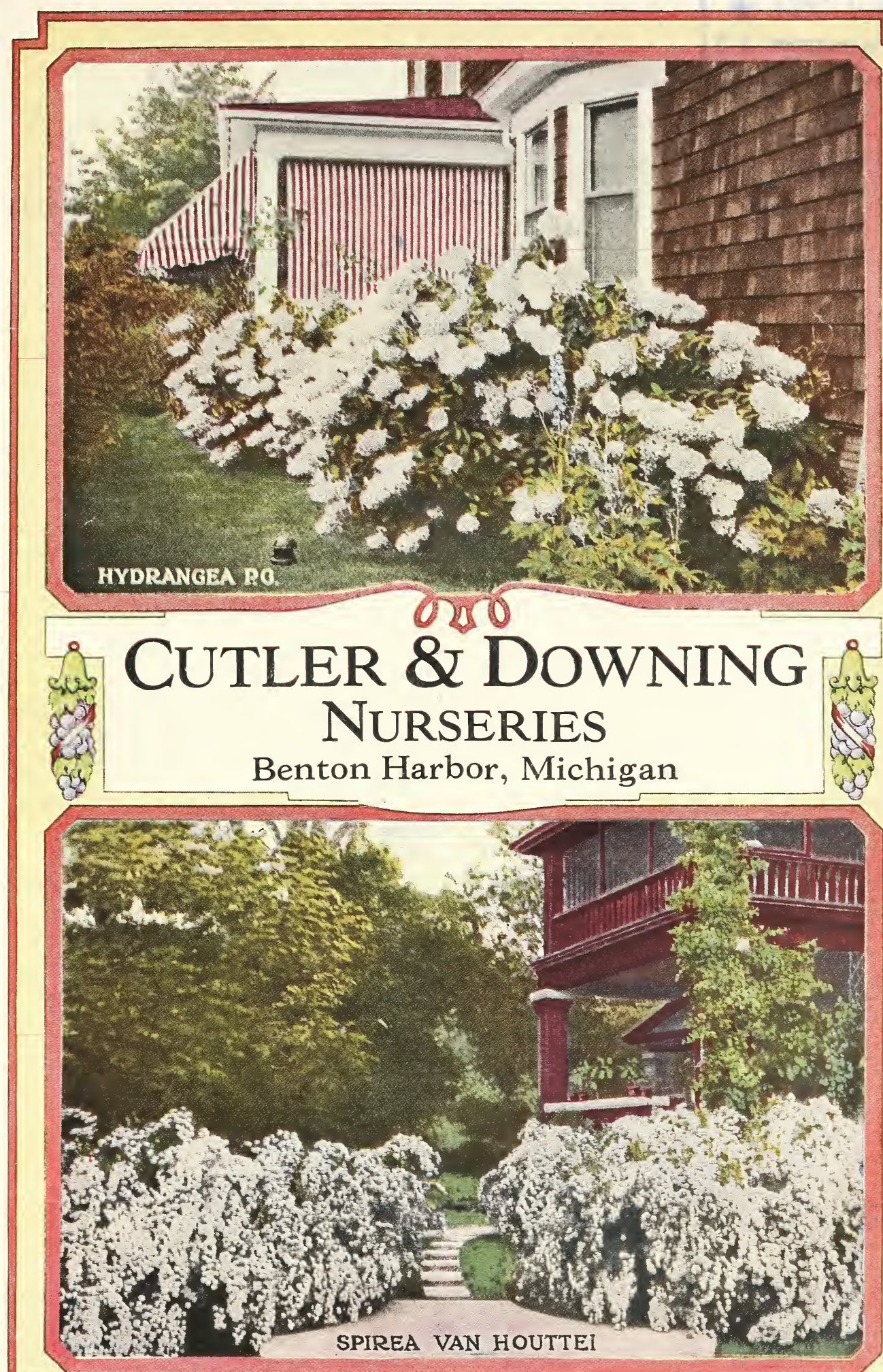


\section{Our Anniversary Catalog}

$\mathrm{W}$ E ARE pleased to submit our anniversary catalog, which marks the 2oth year in the nursery business. The Cutler \& Downing Nurseries originally took the field in 1905 under the personal supervision of $\mathrm{F}$. J. Cutler, who, since that time, has successfully conducted the affairs of the business and who today is president of a concern which has grown from one of the smallest, to one of the largest retail nurseries in this section of the country.

The honest business methods of the concern have won for it a reputation for fair business dealings which is obtainable only after years and years of continuous fair and honest methods. We honestly believe we have more satisfied local customers than any nursery in the country, among them being many who have traded with us continuously for the twenty years we have been in business. Located as we are, in the heart of the Great Michigan Fruit Belt, we have supplied the stock for most of the largest orchards in the state and we now have over two million trees bearing fruit in Berrien county alone.

\section{Terms and Conditions}

PRICES. The price of stock is so changeable that it would be impossible to apply a price in our catalog which would be a fair average, hence, we solicit your correspondence, which wili have our immediate attention.

TERMS. To our old customers we extend unlimited credit. To new customers we must request a satisfactory reference or ask that cash accompany order. Or if C. O. D. shipment is desired, we must request that onethird of amount accompany order.
GUARANTEE. In the event any of our stock is not as represented, we will gladly replace same free of charge or refund the purchase price. Certificate of government inspection will accompany all orders.

All goods travel at the purchaser's risk and expense.

In conjunction with the nursery business, we also handle the following lines: Garden and farm seeds, commercial fertilizers, spraying machinery and materials, shelf and builders' hardware, paints and painters' supplies, factory and mill supplies and sporting goods.

\section{Apples}

The Apple is first in importance of all fruits. It will thrive on almost any well drained soil; its period of ripening, unlike other fruits, extends through a large part of the year, and by making proper selection a constant succession can be obtained. No fruit is more healthful, and for family use there is none more indispensable.

Permanent trees should be planted forty to fifty feet apart, and, as these varieties are usually several years in coming into bearing, fillers of the short-lived varieties are planted between, making the trees twenty to twenty-five feet apart for the first ten or fifteen years, and receiving returns from the fillers almost at once. When the permanent trees need more room for their proper growth and development, the fillers are removed. As Apples require a different treatment than most fruits in cultivating and spraying, we recommend the use of Apple trees as fillers rather than other varieties of fruits.

\section{SUMMER VARIETIES}

Early Harvest. Tree moderately vigorous, upright and spreading. Fruit roundish, medium in size, of a bright straw color, and with smooth skin. Flesh very white, tender, juicy and crisp, with a sprightly flavor, Ripens in July.

Golden Sweet. A fine New England fruit of decided value for domestic stock. Rather large, roundish; pale straw color; sweet, tender and rich. Tree vigorous, spreading, of moderate size and very productive. August and September.
Lowland Raspberry (Liveland Raspberry). Tree perfect and a good bearer; fruit handsomely colored orange-yellow, striped, splashed and shaded with red, showing gray dots through the color; flesh light yellow, often stained with red; fine, tender, juicy, sub-acid, good. Season August.

Red Astrachan. An Apple of great beauty and an abundant bearer. An importation from Sweden. Fruit rather above medium size; color a greenish yellow overlaid with rich crimson and covered with a pale white bloom. Flesh white, crisp, juicy, agreeably acid. Tree vigorous, upright, spreading, and an early bearer. July and August. 
Sweet Bough. A sweet Apple, ripening in harvest time; considered fine for dessert, but too sweet for pies and sauce. Fruit medium pale yellow; flesh white and crisp. Ripens middle of July to 10 th of August.

Yellow Transparent. A Russian variety and especially adapted for a cold climate. Trees bear young, sometimes even in the nursery row. Fruit large, finely formed and showy, a pale yellow in color. Flesh delicate and tender, sprightly, sub-acid, and of good quality. Tree a handsome grower and an abundant bearer. July and August.

\section{AUTUMN VARIETIES}

Chenango Strawberry. Originated in New York. Tree a vigorous grower, spreading, and an abundant producer. Fruit of medium size, somewhat oblong, brightly striped with red and crimson over a whitish ground. Flesh white, juicy, sub-acid, with a most pleasing flavor.

Duchess of Oldenburg. A Russian variety of remarkable beauty, and one of the most hardy and productive varieties under cultivation, doing especially well in sections too cold for ordinary varieties. Tree a vigorous grower and an abundant bearer. Fruit medium in size, with smooth skin, finely washed and streaked with red on a golden ground, covered with a faint bloom. Flesh juicy, sub-acid. Ripens early September.

Fameuse (Snow Apple). Derives its name from the snow-white color of its flesh and is considered one of the best. Tree moderately vigorous, hardy and very productive. Fruit medium size, roundish, somewhat flattened. Color pale yellowish green ground with light streaks of pale red, deepening to a deep red in the sun. Flesh exceptionally white, fine and juicy.

King. One of our hardiest, most valuable and profitable market fruits, especially in the North. Large, globular, yellow, generally striped and shaded with crimson. Flesh yellow, tender, juicy, with a vinous, aromatic flavor. Vigorous and productive.

Maiden Blush. A very desirable variety for cooking or market, also one of the best for drying. Tree handsome, a rapid grower, and an abundant bearer. Fruit beautifully marked with red and yellow, flattened at the ends, and with a waxen appearance. Flesh white, tender and pleasant. September and October.

Wealthy. Originated near St. Paul, Minnesota and is extremely hardy, rich in color and finely shaped. Tree handsome and a free grower Fruit medium, roundish: skin smooth, oily and mostly covered with dark red. Late Fall variety.

\section{WINTER VARIETIES}

Baldwin. Tree vigorous, upright and spreading, and an abundant and regular bearer, doing well in all sections of the country. Fruit large, roundish, yellowish in the shade, but covered with crimson, red and orange where exposed, and with russet dots. Flesh yellowish white, firm, crisp, highly flavored

Delicious. A remarkable new variety rapidly taking first rank both for commercial and home orchards. Fruit large, nearly covered with brilliant dark red; flesh fine grained, crisp, melting and juicy, with a delightful aroma; of the highest quality. A splendid keeper and shipper. Tree one of the hardiest and a vigorous grower.

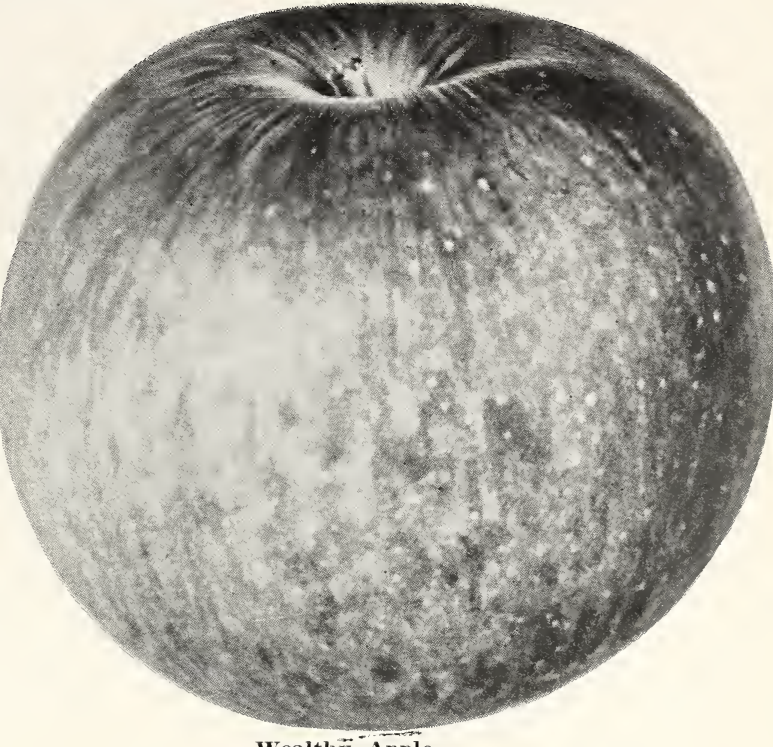

Wealth $\vec{y}$ Apple.

Ben Davis. Fruit large, roundish; skin yellowish, splashed and striped, almost covered with red; flesh white, tender, moderately juicy, sub-acid. Tree hardy and a free grower, bears early; very popular.

Hubbardston. Fruit large to very large, roundish oblong; skin with yellowish ground, striped and spotted with red; flesh yellow, juicy, tender, sweetish and rich. Tree vigorous and productive.

Grimes Golden. A valuable American Apple of extreme hardiness, withstanding injury during the severest Winters, and an annual and productive fruiter. Tree vigorous, upright and spreading. Fruit medium size, yellowish, slightly russetted, fine grained, juicy, rich and spicy. Excellent for dessert. A long keeper.

Jonathan. Originated in New York. Is perfectly hardy, productive in all soils, and succeeds wherever grown. Fruit of medium size, very regularly formed. Skin thin and smooth, with yellow ground almost covered with lively red stripes deepening into dark red in the sun. Flesh white, tender and juicy, with a vinous flavor. Keeps well.

McIntosh Red. Originated in Canada. Tree very hardy and vigorous; a good bearer of handsome fruit of excellent quality, and above medium size. Skin whitish yellow, nearly covered with dark, rich crimson; flesh white, tender, juicy, sub-acid.

Northern Spy. One of the most delicious, fragrant and highly prized of all late dessert Apples. Tree a rapid, upright grower. Fruit large. Skin smooth, greenish or pale yellow in the shade, striped with red in the sun, covered with a thin white bloom.

Northwestern Greening. Originated in northern Wisconsin. Extremely hardy, having withstood 50 degrees below zero without injury. Tree thrifty grower. Fruit large, nearly round and very regular; rich yellow when fully ripe. Flesh yellow, juicy; flavor rich and fine. A long keeper.

Rhode Island Greening. The well-known, large, greenish yellow Apple so much in demand for dessert and cooking. Tree bears regularly and profusely. An Autumn Apple in the South, but in the North keeps through the Winter. 


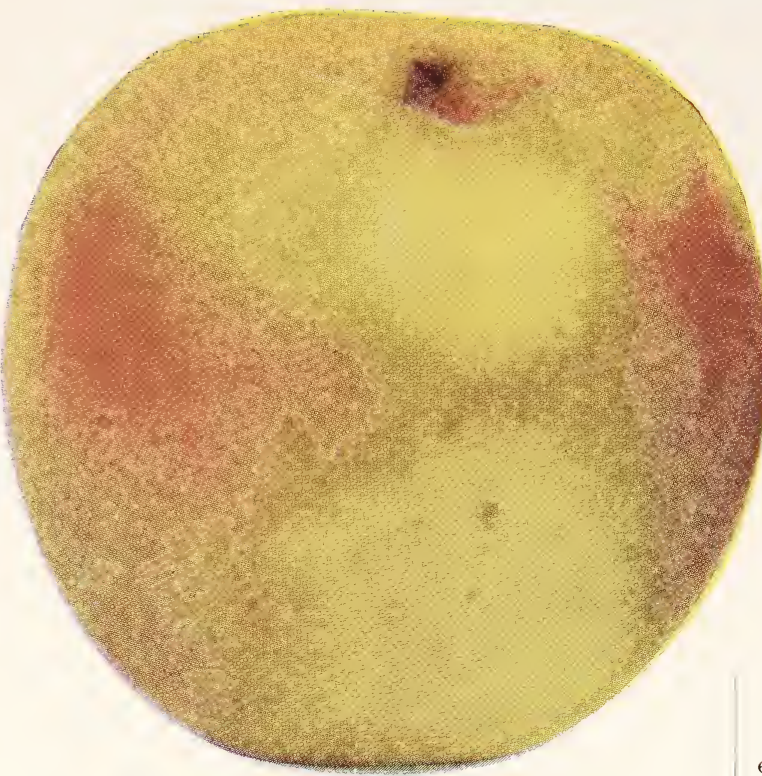

Grimes Golden Apple.

Red Canada (Steele Red). Tree of slender growth, but thrifty and productive. Fruit medium size, oblate. Skin yellow, mostly shaded with deep red, sometimes covered with greenish dots. Flesh very white and juicy, retaining its rich flavor to the last. A long keeper and one of the best.

Whitney. Tree a fine grower, with dark green, glossy foliage. Fruit exceptionally large, with smooth skin, st riped a n d splashed with red. Flesh yellowish white, very juicy and with pleasant flavor. A great bearer and very hardy, and the fruit is equal in size and quality to many Apples.

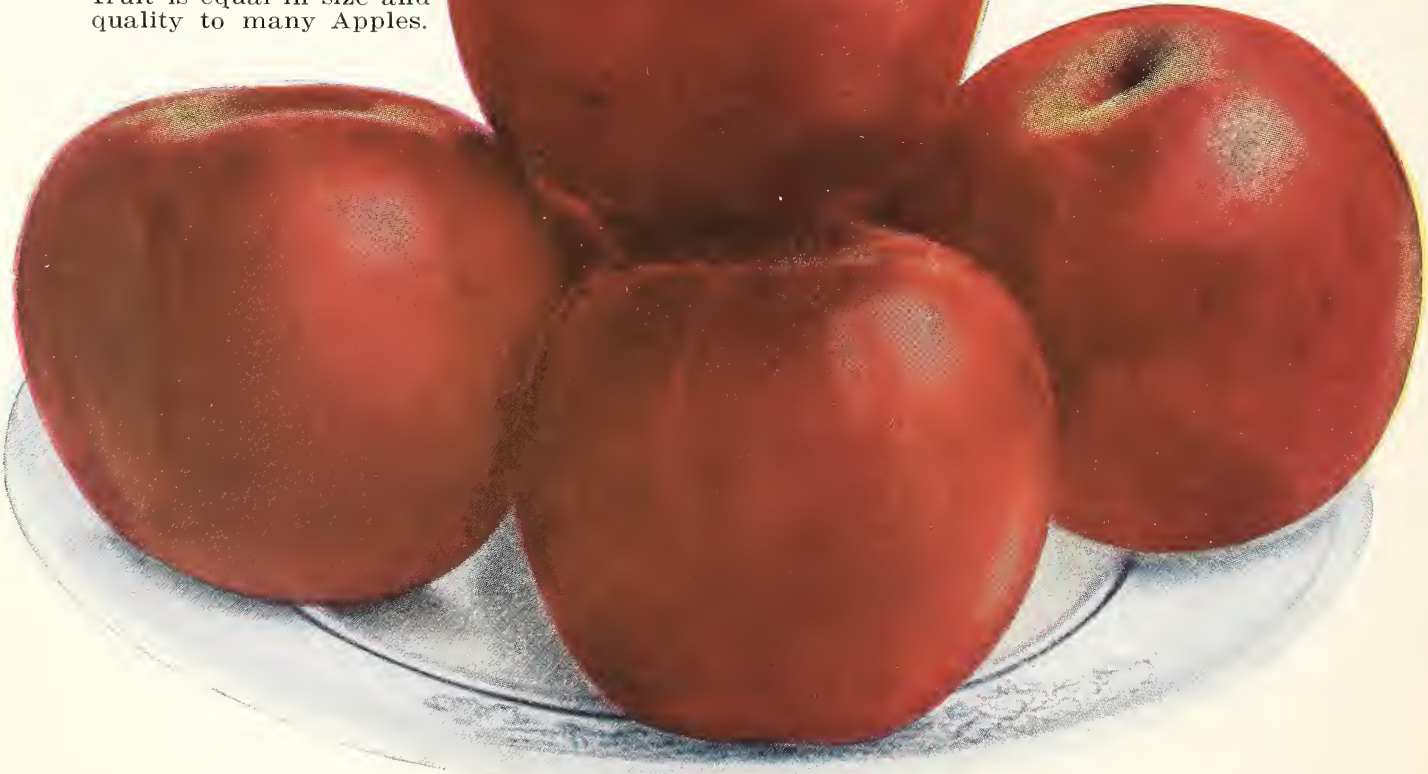

Jonathan Apples.

Rome Beauty. Large, yellow striped and mixed with light red; flesh yellow, subacid.:. Valuable for market on account of its productiveness, size and beauty, as well as for its certain bearing.

Stark. Large; greenish yellow, shaded, splashed and striped with light and dark red; flesh yellowish, moderately juicy. A long keeper, valuable for market. Vigorous and hardy.

Stayman. A seedling of Winesap, but larger and more beautiful; originated in Kansas. Medium to large; oblate-conical; greenish yellow, mostly covered and indistinctly splashed and mixed with dull, dark red, with numerous gray spots. Flesh yellow, firm, tender, juicy, mild sub-acid, aromatic. Quality best.

Talman Sweet. Of medium size; pale yellow, mostly tinged with red; firm, rich, sweet. Most valuable baking Apple.

Winter Banana. Tree hardy and adapted to cold climates; grows to immense size and is wonderfully productive. Flesh golden yellow, fine grained, firm and juicy. Flavor rich, spicy and aromatic.

\section{Crab Apples}

Crab Apples are every year becoming more esteemed and cultivated. They combine to an unusual degree the qualities of extreme hardiness and productiveness, being capable of enduring an extremely cold climate and bearing annually large crops of highly colored and beautiful fruit. The fruit is of the greatest culinary value and is unsurpassed in making jams, jellies, etc., imparting to them a delicate and indescribable flavor obtainable with no other fruit. They should be
grown in every garden if only for this purpose.

Hyslop. Fruit large, produced in clusters, roundish ovate, dark rich red, covered with thick, blue bloom. Flesh firm, yellow, astringent; bears abundantly. Tree hardy, vigorous, spreading. One of the best.

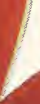




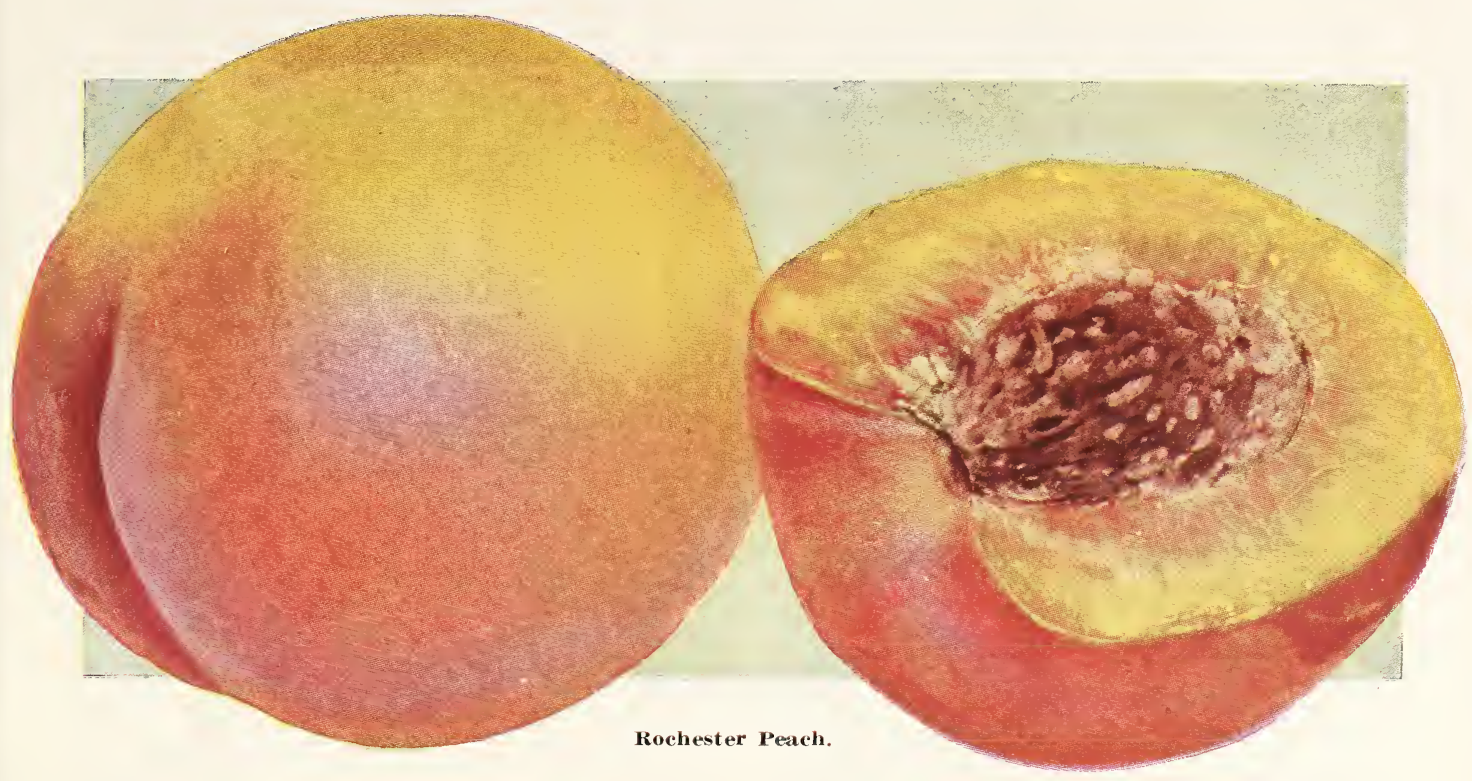

\section{Peaches}

The Peach is one of the most popular fruits grown, and its freedom from disease, ease of cultivation, the short time it takes to come into bearing, and the immense demand for the fruit, makes it extremely profitable.

The best soil for the Peach is a moderately rich, somewhat sandy loam, but it will succeed in almost any soil. The ground should be kept clean and mellow around the tree. Peaches are borne on wood of the previous season's growth and this makes it essential that the trees be pruned yearly, removing all dead branches and enough inside wood to let in light and air. A careful examination should be made each season and all borers removed with a knife. A half-peck of air-slacked lime or leached ashes placed around the trunk of the tree in May and allowed to remain until October affords a good protection against the depredations of this pest.

Admiral Dewey (Semi-cling). Fine size, form and color, with delicious yellow flesh that is firm enough to ship well. The tree is a strong, hardy, symmetrical grower and a good producer. Middle of July.

Carman (Free). Large, somewhat resembling the Elberta in shape; creamy white or pale yellow, with deep blush; skin very tough; flesh tender, juicy and of fine flavor. Prolific bearer and profitable early market variety. August.

Elberta (Free). Originated in Georgia and is regarded as the best market variety. Fruit large, yellow, with red cheek; flesh yellow, firm, juicy and of fine quality. Tree very hardy and exceedingly productive. Very popular and exceptionally large and fine.

Gold Drop (Free). Medium size, golden yellow with red cheek in the sun; flesh yellow, juicy, rich, and very good. Tree very hardy and productive. A valuable variety, and much in demand for canning.

Kalamazoo (Free). Originated in Kalamazoo, attracting attention by bearing regular crops of fruit in a locality where the Peach is considered a failure. A strong grower, bearing loads of fruit when very voung. Medium to large, golden vellow with light crimson cheek; flesh thick. yellow, of superb quality.
J. H. Hale (Free). Very large; globular. Color deep golden yellow overlaid with bright carmine. Flesh solid, deep yellow, delicious flavor. Tree very hardy and productive, similar in growth to Elberta type. An exceptionally fine variety.

New Prolific (Free). A choice large vellow Peach, valuable for its excellent shipping qualities, its beauty and its fine quality. Of strong, thrifty growth, hardy and productive. September.

Rochester (Free). Large yellow and red Peach. Flesh yellow, of fine quality and exquisite flavor. Stone very small and will ship as well as Elberta. The tree comes into bearing when very young, is a strong, upright grower and is as hardy as an oak. Has produced a full crop after undergoing a temperature of 16 degrees below zero, which killed all the buds on Elberta and Crawford in the same orchard.

Salway (Free). Large, roundish; skin downy, creamy yellow, with a warm, rich, clear crimson-red cheek in the sun; flesh deep yellow, stained with red at the stone, juicy, rich, good. Late, ripening ten days after Smock.

Smock (Beers' Smock). (Free). Large orangered or yellow. flesh red at stone, moderately juicy and rich; very productive and a valuable late market variety. October. 


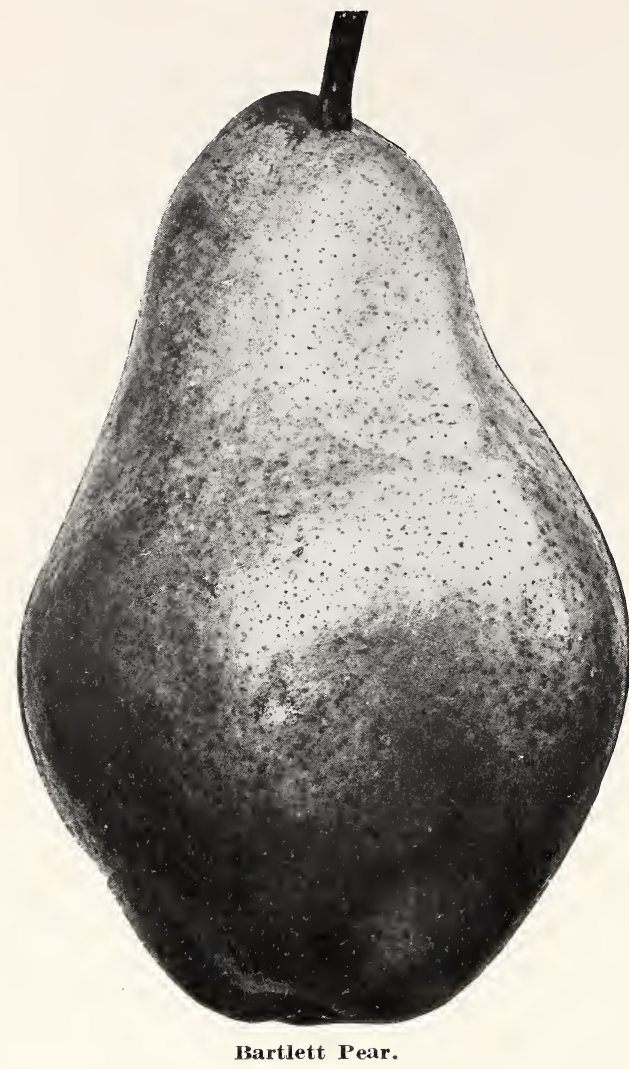

Beurre Bose. Large, yellow, russeted; halfmelting, highly flavored and delicious. Tree a moderate grower, rather erect, and bears well.

Clapp's Favorite. Tree a vigorous, upright, spreading grower, and very hardy and productive. Fruit very large, of uniform size, pale lemon-yellow, faintly splashed with crimson and fawn where exposed to the sun. Flesh fine grained, juicy, buttery and of exquisite flavor.

Howell. Originated in Connecticut. Tree a free grower and is an early and productive bearer. Fruit large and roundish, of a light waxen yellow, sometimes with a finely shaded cheek. Flesh whitish, juicy, melting, vinous.

Kieffer. Tree vigorous, hardy, an early bearer and productive. Fruit large, of fair quality, and one of the most beautiful of Pears in appearance. It thrives in all sections and is a very profitable variety. Apt to overbear and fruit should be thinned to prevent it.

Seckel. Healthiest and hardiest of all Pears, and the standard of excellence in the Pear. Tree a stout, erect grower, bearing regular and abundant crops in clusters at the ends of the branches. Fruit small, but of highest flavor. Pronounced by Downing, the great American horticulturist, to be the richest and most exquisitely flavored variety known.

Wilder. One of the earliest, and a good keeper and shipper. Tree very vigorous and hardy, and bears young and abundantly. Fruit beautiful, bell-shaped, skin smooth, pale yellow with dense shading of brownish carmine. Flesh whitish yellow, fine grained, tender, sub-acid, sprightly. Does not rot at the core, as do some of the early varieties.

\section{Pears}

The Pear very justly ranks as one of the most delicious of fruits, by reason of its fine, juicy texture and exquisite flavor and aroma. Of late years much attention has been given to its culture, and those who have intelligently cultivated it for market have found it to be a profitable occupation.

The soil most congenial to this fruit is a strong clay loam, but it will succeed in any good soil, provided it is moderately rich and dry. A soil saturated with stagnant moisture for a large portion of the year is totally unfit for this purpose. The usual distance for planting is about twenty-five feet each way, but if the soil is very strong, twenty feet is sufficient.

Early and Autumn Pears should be picked ten days before fully ripe and allowed to ripen in the house. This greatly improves the flavor of all kinds, while some are nearly worthless if allowed to ripen on the tree. Winter Pears should be picked before severe frosts and placed in a cool cellar until it is desired to ripen them, when placed in drawers in a warm room, they will ripen in a few days.

Bartlett. One of the most popular Pears. Large, buttery and melting, with a rich, musky flavor. Tree a good, erect grower and bears young and abundantly. A delicious eating Pear and makes the finest of canned fruit.

Beurre Clairgeau. Very large, fine, melting, highly flavored Pear. Tree a good grower, pyramidal in shape, and an early and abundant bearer. Fruit very large, attractive in appearance on the tree and very showy in the market. Color warm yellow shaded with fawn, orange and red. A long keeper and one of the best.

Beurre d'Anjou. Fruit large and handsome, skin greenish sprinkled with russet and sometimes with red cheek. Flesh melting, buttery, perfumed and excellent. A good keeper and considered one of the best.

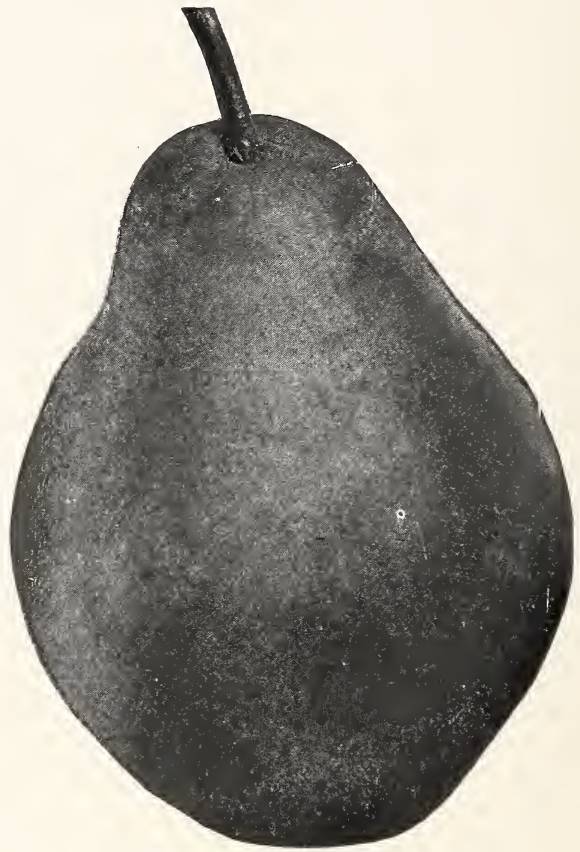

Clapp's Favorite Pear. 


\section{Plums}

The Plum attains its greatest perfection on strong clay soil, where it grows most thriftily and suffers the least from Curculio and Black Knot. However, there are some classes that do very well on light soil; as in the case of other fruits, they are greatly benefited by thorough cultivation. With only reasonably good care and culture the trees can be kept in healthy condition and bear fine crops of fruit. Annual spraying with Bordeaux Mixture prevents leaf blight and fungus, and is also protection against Black Knot. Should the latter appear, clean and prompt cutting away and burning all the diseased wood holds it well in check. The Curculio is destroyed by jarring the tree in early morning when the insects are dormant. A sheet is spread under the tree to catch the insects and stung fruit, all of which is destroyed. The work must be done daily, if the insects are numerous, for two weeks or more after the bloom falls from the tree. This sounds arduous, but it does not take much time. The cost of protecting large orchards from the attacks of the enemies will not exceed ten cents per tree for the entire season.

Abundance (Botan). (Japanese). Large to very large, oblong, amber, nearly covered with bright red and over-spread with a thick bloom; flesh orange-yellow, juicy, melting and of delicious sweetness, stone small and flesh parts readily from it. Tree strong grower and an early and profuse bearer. Ripens in advance of other Plums. Valuable for canning and market.

Blue Damson (European). Small; black with thick blue bloom; free; flesh juicy but rather tart; best for kitchen and market. Tree enormously productive and hardy. September.

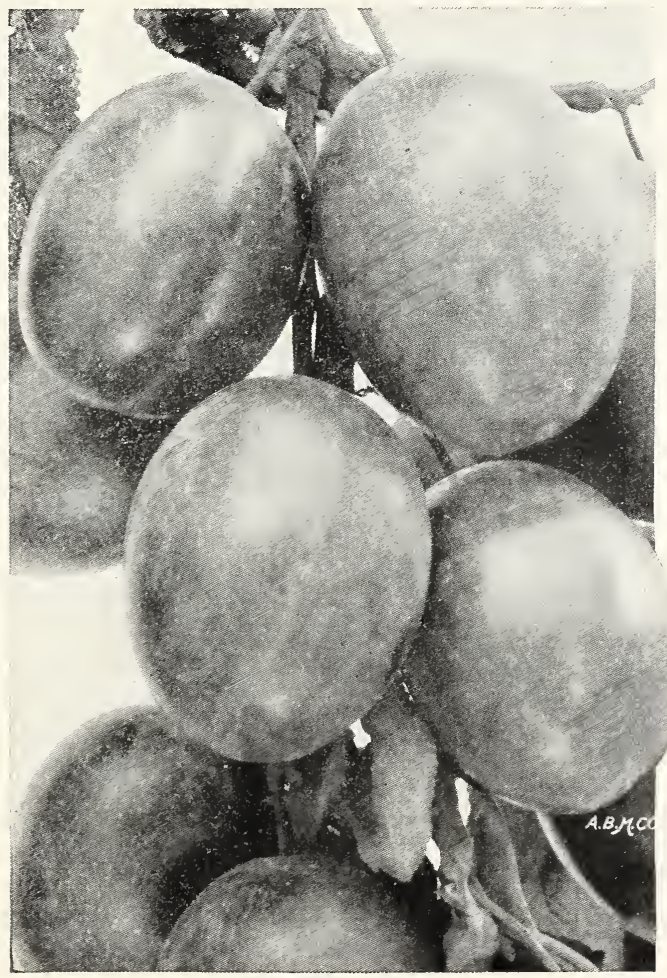

Bradshaw Plums.

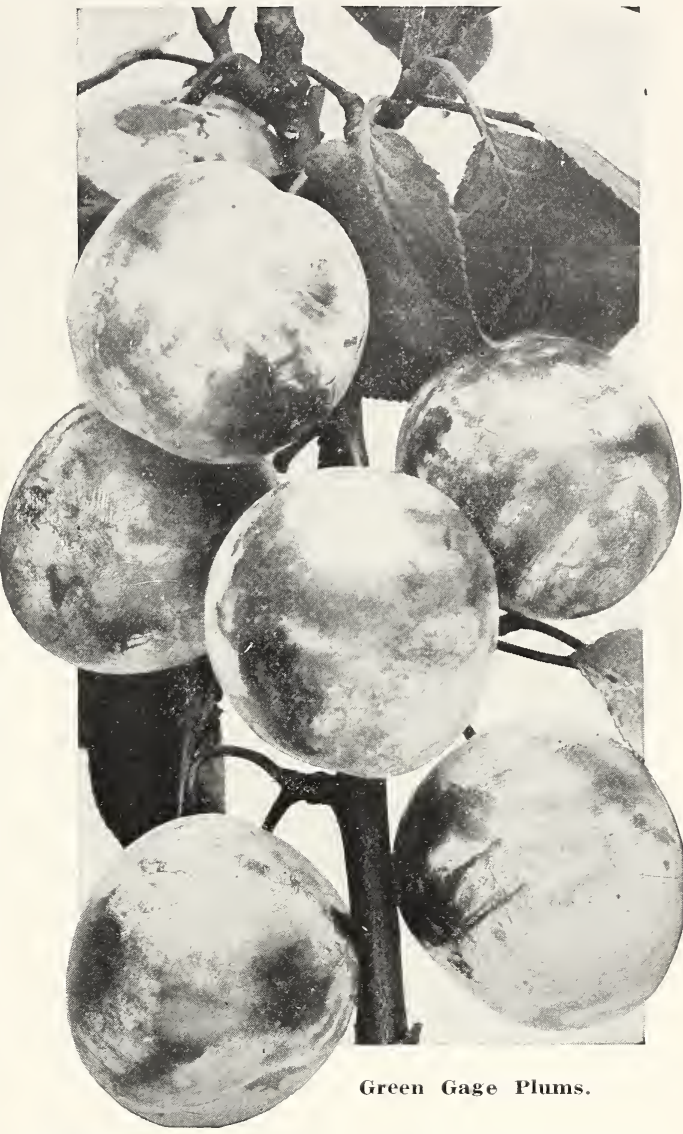

Bradshaw (European). A very large and fine early Plum, pronounced by Plum growers to be a most valuable market sort. Fruit is very large and oval. Color reddish purple, covered with bloom. Tree ironclad in hardiness, strong grower, enormous bearer. Ripens September 5 th to $10 \mathrm{th}$.

Burbank (Japanese). The Burbank Plum stands at the head of the celebrated Japanese varieties, is practically Curculio proof, and is perfectly hardy (said to stand 30 degrees below zero). Ripens in August. It seems to succeed on any soil, sand, clay or loam. It can be picked green, and will ripen and color up perfectly and will not lose flavor. Will keep fully two weeks in perfect condition after ripening. Abundant yearly bearer, fruit large, roundish, dark red or purplish, with thin lilac bloom, flesh amber yellow, melting, juicy, with rich sugary flavor; stone small and free. Bears second year after planting.

IClimax (Japanese). One of Burbank's latest and best achievements. The Wickson is called the Queen and the Climax the King of Plums. Fruit is heart-shaped and highly colored. Fragrant and very delicious; tree early and prolific bearer, and a vigorous grower.

German Prune (European). A valuable Plum of fair quality for dessert, but most esteemed for drying and preserving. Large, long-oval, purple, with a thick blue bloom; flesh firm, sweet and pleasant, separating from the stone. Moderate to vigorous in growth. September. 


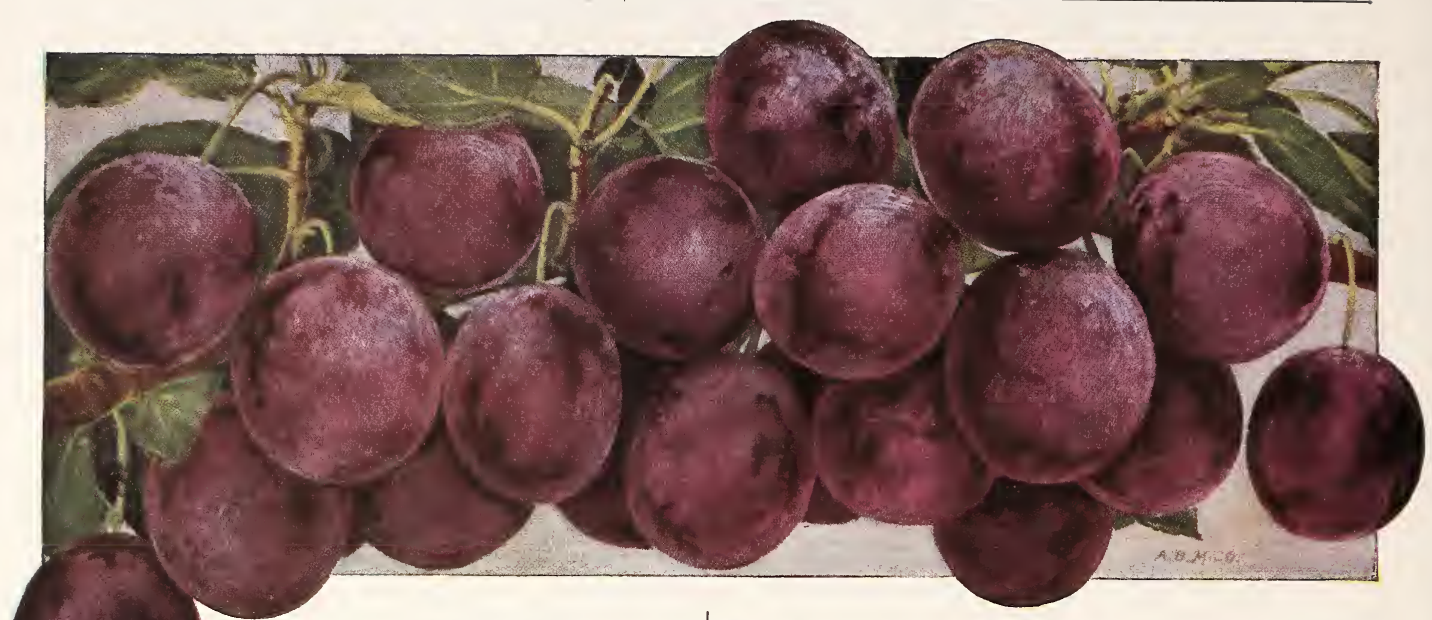

Monarch Plums.

Momarch (European). Fruit dark purple, covered with a thin bloom; large size, specimens measuring six inches in circumference; flesh pale greenish yellow, parting freely from the stone; juicy, with a pleasant flavor. It is a leading market sort. Tree is a vigorous grower. September.

Green Gage, Bavay's (Reine Claude de Bavay). (European). Medium size, roundish, oval; skin greenish yellow, marked with red in the sun; flesh yellow, juicy and of excellent flavor. Tree a good grower and productive. Last of September.

Lombard (European). Medium size, oval, violet-red; flesh yellow, juicy and pleasant. A creat bearer, and particularly adapted to light soils. Tree vigorous and hardy; succeeds when most other varieties fail. The most popular and profitable Plum under general cultivation. Last of August.

Shipper's Pride (European). Large size, dark purple, handsome, showy, flesh firm and excellent. Promises to be a superior market sort. Tree hardy, productive. Fore part of September.

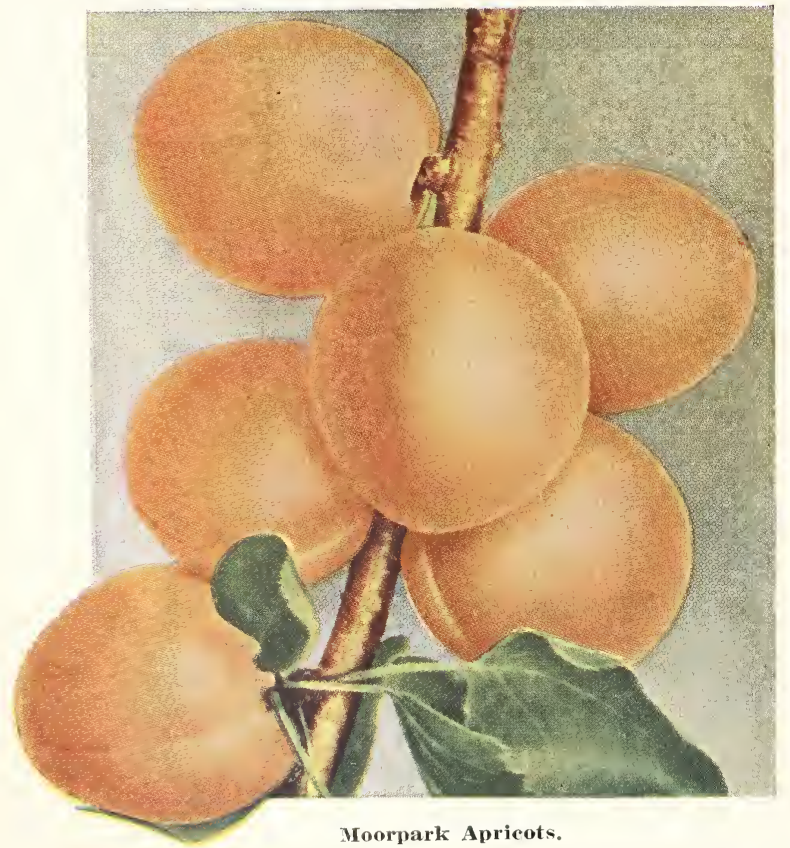

Shropshipe Damson (European). Fruit small, oval; purple, with blue bloom; melting and juicy, rather tart. Character varies somewhat. September.

\section{Apricots}

The Apricot is one of the most delicious of our dessert fruits. It ripens between cherries and plums. The remarks on the Curculio, under the head of plums, are applicable to the Apricot. The tree may be trained on walls, but a northern or western exposure is better.

Iexander (Russian). One of the best of this new class. Large, oblong: mottled with red; flesh yellowish, sweet and of delicious flavor. The tree is very hardy and an immense bearer. July 1 st.

Harris, A remarkably fine variety, succeeding well wherever tested. Large, roundish, with deep suture; rich golden yellow, with faint blush; excellent quality and freestone. An early and abundant bearer. First of July.

Mooppark. One of the largest and finest Apricots; yellow with a red cheek; flesh orange, sweet, juicy and rich; very productive.

\section{Mulberries}

These are sometimes classed among ornamental trees on account of their large, handsome leaves, dense shade, and fine, compact growth. All the kinds are productive; the everbearing sorts fruit for three months. Mulberries are much relished by poultry:

Downing:s Everbearing. A fine rapid growing tree with large foliage and attractive for the lawn, and at the same time bears a delicious fruit for about three months.

New American. Fruit large, black, of fine quality, and tree vigorous, a good bearer and highly ornamental for the lawn.

Russian. Tree a rapid grower and considered very hardy and valuable for timber. The fruit is of medium size and good. The foliage is abundant and said to be be valuable for silk culture. 


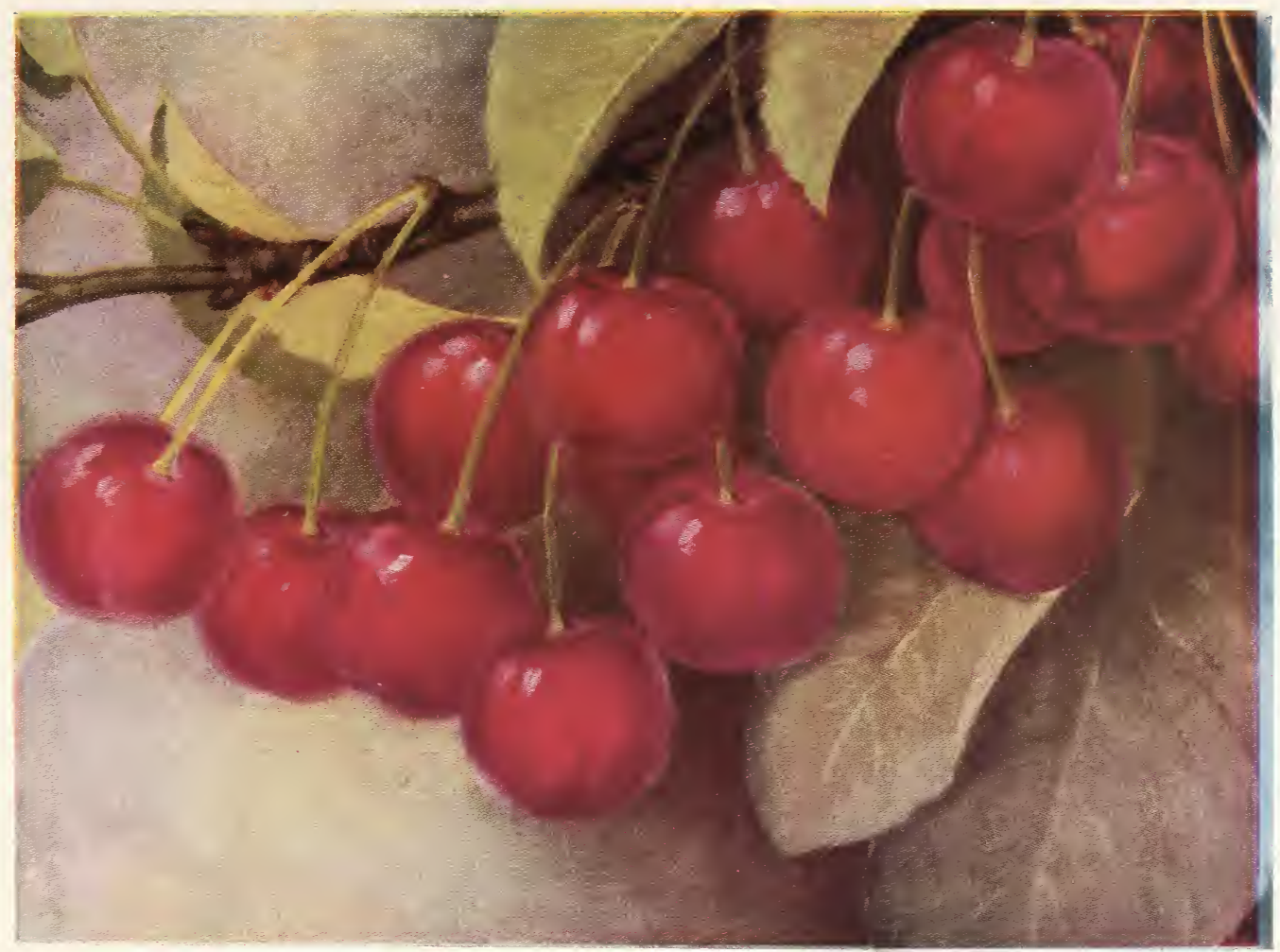

Montmorency Cherries.

\section{Cherries}

The Heart and Bigarreau Cherries are rapid growing trees, with large foliage and sweet fruit, somewhat difficult to establish and do not succeed uniformly in all parts of the country. The Duke and Morello classes, easily distinguished by their more spreading and slender branches, smaller foliage, and most round-shaped, acid fruit, are hardier, less liable to crack, and, being generally productive, are the best for planting where the Heart and Bigarreau varieties do not do well. The Cherry does best on a light, dry, sandy or gravelly soil. Plant Sweet Cherries 18 to 20 feet apart and Sour Cherries 15 to 18 feet.

\section{Heart and Bigarreau Cherries}

Bing. This grand new black Cherry was originated by Seth Luelling, of Milwaukee, Oregon. Size very large; black-purplish. Flesh very solid, flavor of the highest quality. Tree thrifty, upright grower; very hardy and productive. A fine shipping and market variety.

Black Tartarian. Very large, purplish black, half tender, mild flavor and pleasant. One of the most popular varieties. Last of June and beginning of July.

Governor Wood. Fruit large, roundish, heartshaped, light yellow, shaded with bright red, tender, juicy, rich and delicious. Tree vigorous and productive. End of June.

Lambert. In size the largest known; smooth, glossy skin, color dark purplish red, with numerous minute, indented russet dots; flesh dark purplish red, with whitish veins, firm, meaty texture, small oval stone, semi-cling: flavor sweet or very mild; sub-acid, rich and of highest quality; form roundish, heartshaped, long, slender stem. Tree thrifty, hardy and vigorous grower.

Royal Anne (Napoleon Bigarreau). A magnificent Cherry of the largest size; pale yellow, with bright red cheek in the sun; flesh very firm, juicy and sweet. Beginning in July.

Schmidt's Bigarreau. This remarkable Cherry is of Belgian origin. and is one of the largest of the black Bigarreau Cherries. Fruit large size, of a deep mahogany color: flesh dark, tender, very juicy, with a fine rich flavor. Grows in clusters. An excellent shipper, being firm and most attractive. Tree very hardy, a strong and vigorous grower.

Windsor. New; introduced from Canada. Fruit large, liver colored, resembling the Black Heart, but quite distinct; ripens a few days earlier than that variety; flesh of fine quality. Tree hardy and very prolific.

\section{Duke and Morello Cherries}

Early Richmond (Early May, or Donna Maria). Medium size, dark red, flesh tender, juicy, rich, somewhat acid. Tree vigorous, profuse bearer, one of the best of its class, unsurpassed for cooking and preserving. Isast of Nay to first of July.

Late Duke. Large, light red, late, excellent. Tree makes a nice dwarf or pyramid. Valuable. End of July.

May Duke. An old, well-known, excellent variety; large, dark red, sub-acid, rich. A superior and productive old sort that holds its own well against newcomers. Niddle of June.

Morello, English, Large, dark red, nearly black; tender, juicy, sub-acid, rich. Season last of July and first of August.

Montmorency. Large, red, rich, acid. Very hardy and productive. A week or ten days later than Early Richmond. A Cherry of the Richmond class, but larger and more solid; strong, upright grower. Very valuable. 


\section{Strawberries}

Any soil that will grow a good crop of corn or potatoes is suitable for Strawberry culture, but they should not be planted on low or marshy ground where late frosts are liable to occur. The ground should be well pulverized and mellow when plants are set, and shallow cultivation should be started at once and kept up during the growing season. Cultivating too deep or too close to the plants is injurious to the roots. Set plants 18 inches apart in the row and the rows $3 \frac{1 / 2}{2}$ feet apart. For garden use, they may be set closer, making the rows 2 feet apart, three plants 12 inches apart in the row.

Brandywine (Per.) The berries are glossy crimison, very handsome, firm and solid, excellent in quality, with fine aromatic flavor. The berries color all over evenly and retain a good size to the last, ripening in succession, and every berry maturing fully. Plant is remarkably vigorous, hardy and exceedingly productive and its foliage is long, clean and healthy.

Gandy (Per.) This is one of the most reliable large, late berries that is grown. It is one of the old standard varieties that you can depend upon. The plant is a strong grower, a good plant maker. The large, handsome appearance of the fruit always commands for it a high price in the market. The fruit always grows large and is one of the best shipping varieties known.

Gibson (Per.). Midseason, about the same as Dunlap. Fruit stems are large and strong, holding fruit well up from the ground. The foliage is strong and amply protects the fruit. The berry is a rich red color, being red to the core, which makes it a valuable berry for preserving. It is a large berry, being regular in form and continues good size until the very last picking.

Senator Dunlap (Per.) It is unusually healthy and vigorous, adapting itself to any soil or climate. The fruit is medium large, conical in form, regular in size, and never misshapen; dark glossy red in color. It is a splendid keeper and shipper, most excellent in cuality, making it a popular berry for either market or canning.

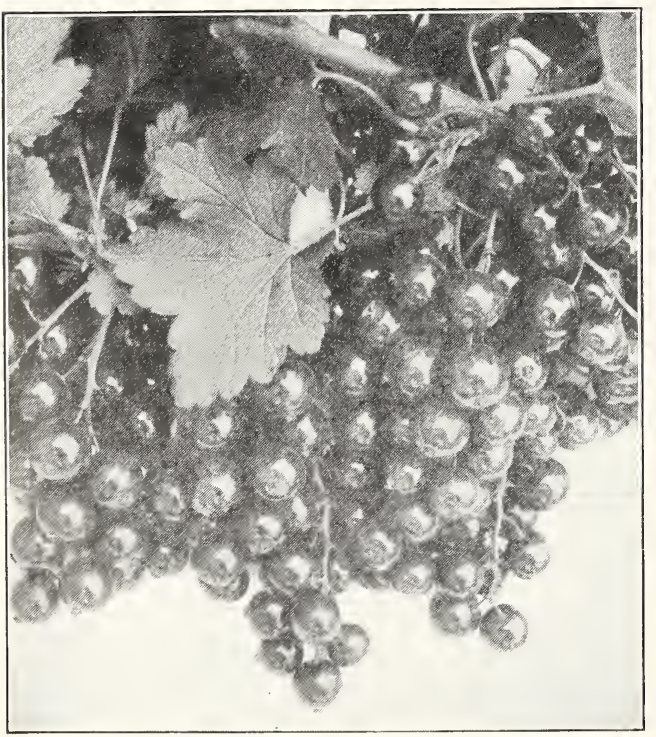

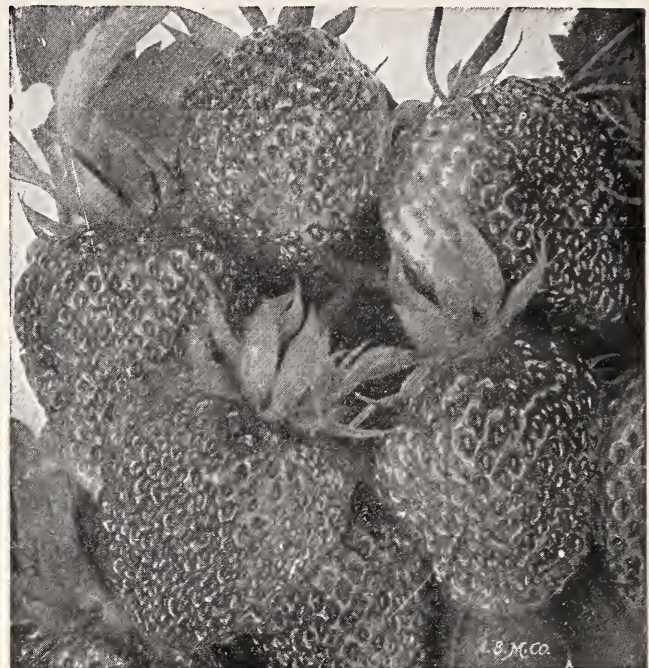

Gibson Strawberries.

Warfield (Imp.) A well known variety of excellent quality, a good market variety and a splendid canner. While the individual plants are quite small and usually have only one fruit stem, it is often remarkable the number of quarts produced by a lightly matted row.

Progressive Everbearing (Per.) This variety is very productive and a sure cropper every season. If the blossoms happen to get killed by the late frosts in the Spring, the plants will throw up new fruiting stems, and produce a full crop just the same as if nothing had happened. This feature alone should justify every grower in planting the everbearers. Plants are medium in size, very thrifty, and full of vitality, and on a fairly rich, moist soil, are good plant makers. Fruit is medium in size, and in shape similar to the Dunlap. Firm, of good quality and color.

\section{Currants}

The Currant, although a small fruit, is very easily raised. The old wood should be cut out and the plants kept well manured. An easy method of destroying the currant worm is by the use of powdered white hellebore. One or two applications are generally sufficient.

Fay's Prolific. The leading market variety. Extra large stems and berries, uniform ir size, easily picked, exceedingly productive. London Market. A particularly valuable variety" for northern climates. The plant is extremely hardy and vigorous, and retains its foliage throughout the season. Beautiful in color, large in size and a very heavy cropper. Ships well, and is excellent for market either near or distant.

Perfection. The latest introduction, created by crossing Fay's Prolific with White Grape, and combines the best qualities of both parents. In color it is a beautiful bright red and of a size larger than the Fay; the clusters average longer and the size of the berries is maintained to the end of the bunch.

Wilder. A remarkable new variety, for which is predicted a great future both for table and market; strong grower; enormously productive; bunch and berry very large, bright red and of highest sub-acid quality.

White Grape. A very large variety. Plant quite distinct from the other white varieties. A great bearer. Should be in every collection. 


\section{Gooseberries}

The Gooseberry requires a deep soil, well manured, and, if inclined to be dry, should be mulched to retain the moisture. The bushes should be thoroughly trimmed and pruned to obtain large, fine fruit.

Downing's Seedling. Origin, Newburgh, N. Y. Fruit larger than Houghton, roundish, light green, with distinct veins; skin smooth; flesh rather soft, juicy and very good. Vigorous and productive.

Pearl. An exceedingly prolific variety that has been well tested and ranks No. 1 in healthfulness and productiveness. Same color as Downing; seems to possess all the good points of that variety. Valuable for home use and market.

Smith's White. Bush moderately vigorous and very productive; fruit large, pale yellow and thin skin; excellent quality for dessert or cooking.

\section{Quinces}

Apple or Orange. Large, roundish, bright golden yellow. Very productive and most desirable variety. Ripens in October.

Bourgeat. A new variety, of the best quality, tender and good. Ripening shortly after Orange, and keeping till past midwinter. Largest size, rich golden color, smooth, no creases. Rich velvety skin with delicious Quince odor. Foliage healthy. The strongest grower of the Quinces, making a tree as large and thrifty as plums and pears, and yielding an immense crop.

Champion. Large to very large, oblong; skin russetted about the stem, and of a bright yellow color; flesh tender and of good quality. Tree an early bearer and very prolific. Ripens about two weeks after the Orange Quince.

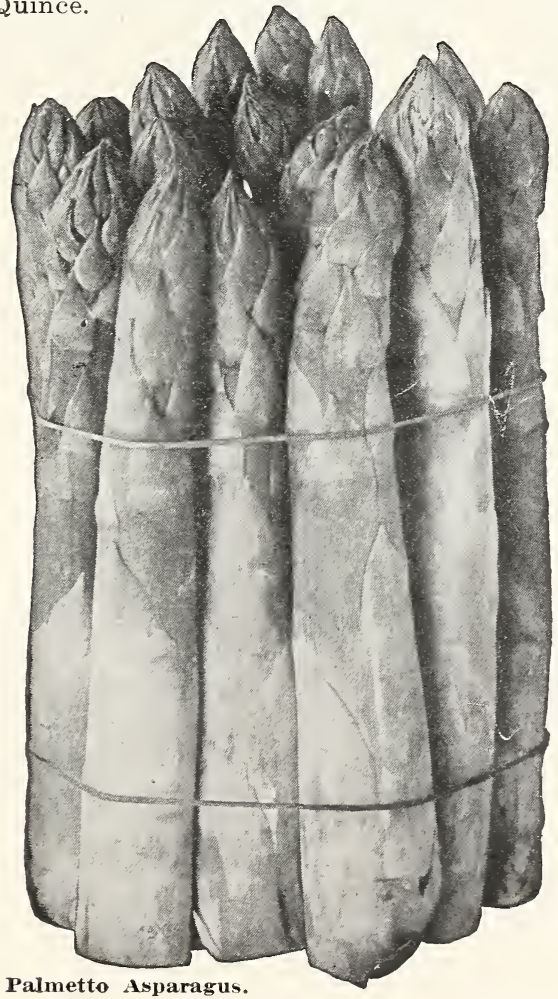

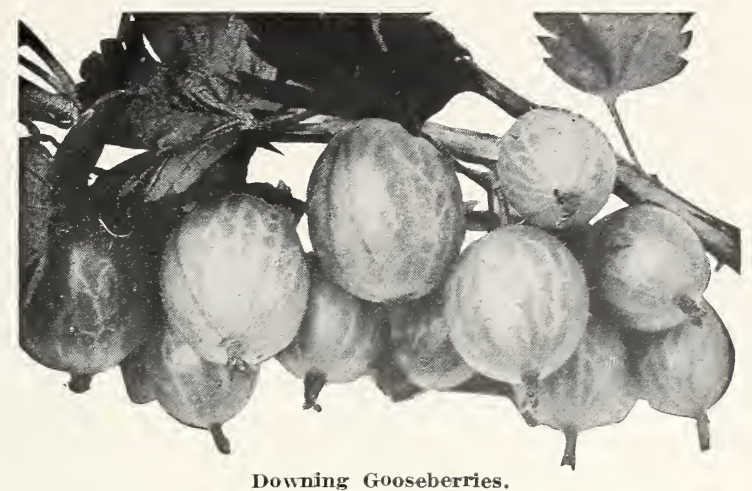

Esculent Roots

\section{Asparagus}

Prepare the ground by trenching to the depth of two feet, mixing each layer of soil as turned over, with two or three inches of well-rotted manure. For private use or for marketing on a small scale, beds should be formed five feet wide, with three rows planted in each; one in the middle and one on each side, a foot from the edge; the distance of the plants in rows, nine inches; the alleys between the beds should be two feet wide.

Martha Washington. This wonderful new rust resistant Asparagus is the result of many years of breeding and research work by the United States Department of Agriculture. Martha Washington Asparagus is fast growing. The shoots are a most beautiful dark green with a heavy purple tinge, and exceedingly tender. The flavor is most excellent, of a peculiar and pleasing sweetness. Many of the stalks are more than one inch in diameter, and wherever tested this variety has proven superior to every other.

Palmetto. Of Southern origin, has been planted in different parts of the country with good success. It is a good yielder, of even and regular growth, earlier than Conover's Colossal, and of best quality.

\section{Rhubarb}

A very early vegetable, the large stems of which are used for pie making and stewing. It is also valuable for medicinal purposes. A deep, rich soil is indispensable to secure large, heavy stalks. Plant in rows four feet apart, with the plants three feet distant. Set so that the crowns are about one inch below the surface. Top dress in the Fall with stable manure and fork under in the spring.

Mammoth Victoria or "Strawberry." Leaf stalks tall and large, sometimes weighing two pounds each. Skin thick and red stained. Pulp juice acid.

Myatt's Linnaeus. Early, very tender, and has a mild sub-acid flavor, not "stringy" or tough. The plant is large, and for pies or other culinary purposes it is the housewife's favorite. 


\section{Grapes}

The culture of the Grape within the past few years has attracted a great deal of attention throughout the United States. Many vineyards of large extent have been and are still being planted in various parts of the country, and are proving a great pecuniary success.

The Grape is one of the least particular of any of the fruits in regard to soil and will succeed almost anywhere. It may be trained on trellises, arbors, pergolas or fences and become ornamental as well as useful.

Agawam (Rogers' No. 15). (Red). A dark red Grape of the Hamburg cross. Bunches large, compact, frequently shouldered; berries large, with a thick skin, pulp soft, sweet, sprightly; vine very vigorous. Ripens early.

Catawba (Red). Well known as the great wine Grape of Ohio, Kentucky, etc. Bunches large and loose; berries large, of coppery red color, becoming purplish when well ripened. Requires the most favorable soils and situation, good culture and warm seasons to mature.

Campbell's Early (Black). Strong grower, with large, healthy foliage; productive; its keeping and shipping qualities are equaled by no other early Grape. Ripens with Moore's Early, but will keep in sound, perfect condition long after that variety is gone. Bunch and berry large, glossy black, with blue bloom, sweet and juicy, seeds few and small, part readily from the pulp. Stands at the head of early black Grapes for quality.

Concord (Black). One of the best, well tried, native Grapes. I.t is of very large size, both of bunch and berry, quality good, color black, covered with a thick, bluish bloom, flesh moderately juicy, rather buttery, very sweet. It is perfectly hardy, vigorous in its habits of growth, very healthy and very productive.

Delaware (Red). This fruit has fully maintained its high reputation as one of the finest of our native Grapes. The vine is comparatively slender, but grows freely. It proves quite hardy in this climate, and ripens two or three weeks before the Isabella. Bunch small and compact, berries small, clear red, beautiful, sweet, sugary and vinous.

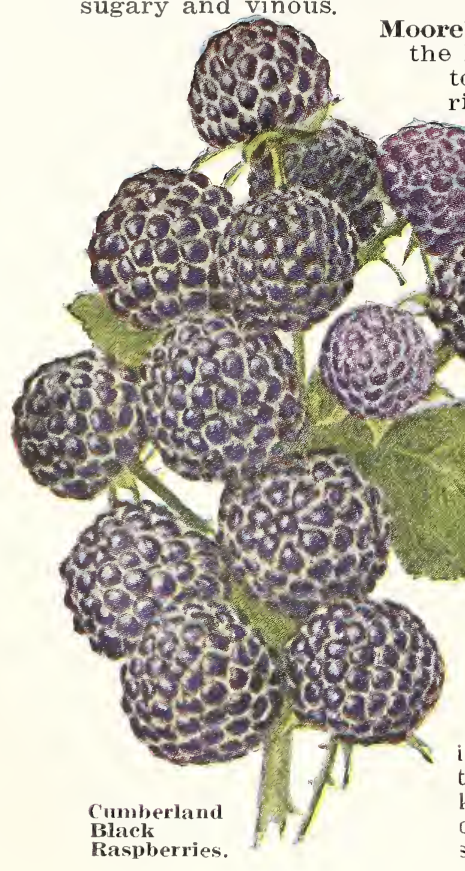

Moore's Diamond (White). 'Originated by Jacob Moore, the producer of the Brighton, and seems destined to become very popular; equal in size to Concord; color greenish white with a rich yellow tinge when fully ripe; flesh tender, juicy, nearly transparent and very good, vine vigorous, hardy and productive. Ripens two weeks before Concord. Entirely free from mildew, and a prolific bearer. Moore's Early (Black). A $\$ 60$ prize Grape of the Massachusetts Horticultural Society. Promises to be a valuable acquisition. Berry very large, black, bunch medium, quality very good. Ten days earlier than Concord.

viagara (White). This white Grape has attracted the most attention of any new fruit recently introduced. The vine is a strong grower, healthy and prolific; bunches large, uniform and compact; berry large; skin greenish white, slightly ambered in the sun; quality good. Ripens with Concord. Skin tough, making it a good shipper and market Grape.

Worden (Black). Promises to be very popular. Bunch large, shouldered and handsome; berry large, black; skin thin; flesh sweet, much like the Concord, and ripens a few days earlier. Vine hardy, vigorous and productive.

\section{Raspberries}

The Raspberry is a valuable and easily grown garden fruit It is successful in most northern states. Plant in rows seven feet apart and three feet in the row. In the North it is best to plant both Raspberries and blackberries a little below the level so that they can be covered easily in the Fall. Cultivate thoroughly, and when the young shoots are fifteen or eighteen nches high, pinch them off, thus causing laterals to push out. In the Spring cut these back to twelve or fifteen inches. In order to keep a bed in good condition, the old and dead wood should be cut out as soon as the crop is gathered. The ground should be well spaded and a top dressing of manure put on. 


\section{Red Varieties}

Columbian. This variety ranks very near the top for amazing productiveness, vigor and the quality of its very large, dark red fruit. Unexcelled for market and all culinary uses.

Cuthbert (Queen of the Market). The most valuable red berry for market, also one of the best for home use. Fruit medium to large, rich crimson, very handsome, quite firm, juicy, sweet, very good, hardy and productive.

King. One of the very earliest berries on the market; a wonderful producer, and fruits through a long season. The berries are very large, firm and finely flavored, pick easily and do not crumble. Becoming too ripe does not affect the bright red color. A showy fruit, perfectly hardy and healthy, and one of the most sirable Raspberries grown.

St. Regis. Berries bright crimson, large size, rich, sugary, with full Raspberry flavor. Flesh firm and meaty; a good shipper. Canes stocky, of strong growth, with abundance of dark green, leathery foliage. St. Regis is proving one of our most profitable early red Raspberries, outside of being a producer of nice berries all through the late summer and Fall.

\section{Black Cap Varieties}

Cumberland. A mammoth midseason Blackeap that loads its stout, stocky canes with handsome fruit. Its great glossy berries outsell all others of their season, are firm enough to ship well, and of good quality. Ripens with Gregg.

Gregg. Of good size, fine quality, productive and hardy, firm, sweet and rich; strong grower and good bearer; ripens late and

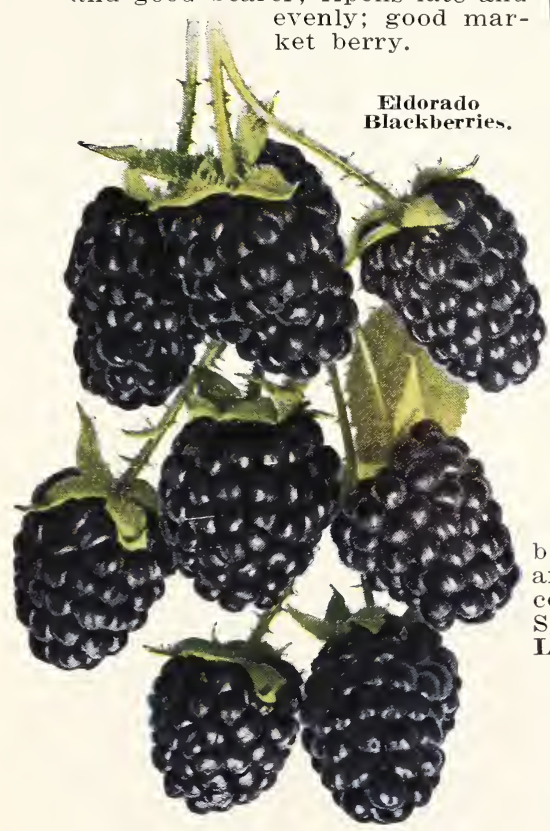

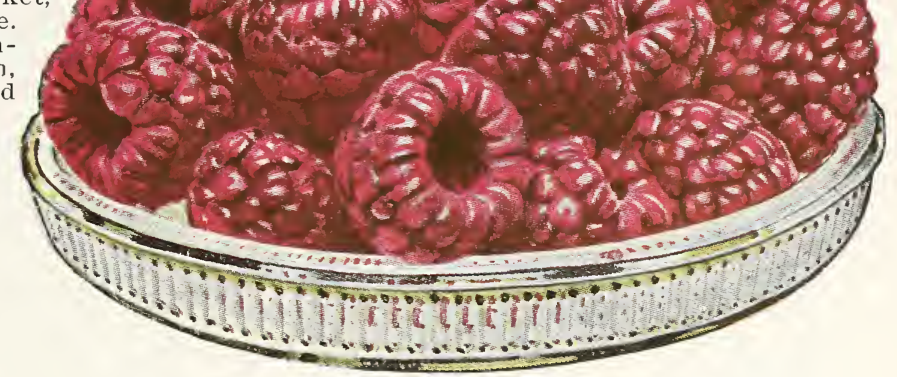

King Red Raspberries.

Flum Farmer. The plants are very healthy, have a silvery bluish appearance when ripened in the Fall and succeed where others fail. The fruit is grayish black, very firm, a good shipper, attractive, of the very highest flavor and is adapted for evaporating, as well as for fresh market or home use.

\section{Blackberries}

There should be in every collection a few plants of this delicious, healthful fruit, as it requires but little care and expense, and is an excellent table fruit. The plants should be set from four to six feet apart in a moderately rich soil. Mulching, staking and an occasional pinching-in during the growing season will be accompanied with good effect in productiveness and size of fruit.

The Blackberry, as a rule, outyields all other members of this family, and is usually one of the most profitable to grow, when properly managed, providing climatic conditions are favorable. Cultivation should be frequent but shallow; deep cultivation disturbs the roots and induces increased suckerings.

The Blowers Blackberry. Originated by Mr. Plowers of Chautauqua County, N. Y. Said to be exceedingly sweet, with no perceptible core when fully developed; a remarkable grower, producing as high as 2,750 quarts from one-third of an acre. The canes grow upright and are perfectly hardy. The berries always bring the highest price on the market.

Eldorado. The vines are very hardy and vigorous, enduring the Winters of the far Northwest without injury, and their yield is enormous. The berries are large, jet black, borne in large clusters and ripen well together; they are very sweet, melting, have no hard core and keep for eight or ten days after picking with quality unimpaired. Perhaps the most valuable sort in cultivation.

\section{Dewberries or Trailing Black- berries}

The Dewberry is a dwarf and trailing form of the Blackberry. Highly prized as a market fruit owing to its large size and fine quality. Set the plants two feet apart in the row and cover in Winter with coarse litter. Should be mulched in the Spring to keep them off the ground.

Lucretia. The very best of the Blackberry family. Berries are far larger and incomparably better than any Blackberry: of unequaled excellence. The Lucretia Dewberry has received the highest praise from the best horticulturists in the country. Its trailing habit renders it less liable to winter kill. The bush is very hardy and a great bearer, fruit large, black and glossy, without hard core, and very delicious. Ripens with early Blackberries. 


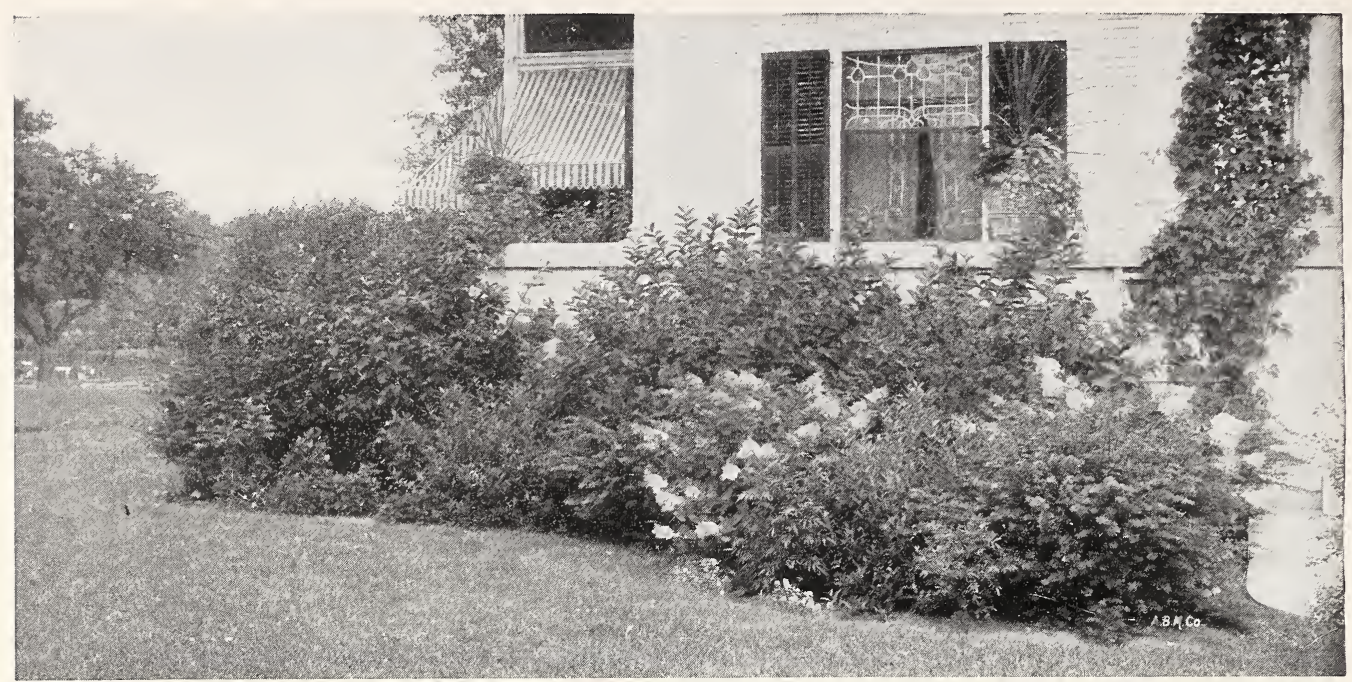

An Attractive Foundation Planting of Shrubbery.

\section{Ornamental Department}

The beauty of grounds that are planned with taste and given proper care appeals to most people, but many fail to discover that they can make their own home equally beautiful. They perhaps have tried growing a few shrubs or roses in a thick turf, and without giving attention to either cultivation or pruning have wondered at their lack of success, while good results could not be attained in any line under such circumstances.

Beautiful surroundings need not appeal to our taste for the beautiful only, but from a commercial standpoint the beautifying of the home greatly adds to its value. Who, in seeking for a home would pass a house surrounded by a lawn judiciously planted to shrubs and trees which had been tenderly cared for for years, and choose one barren of tree, shrub or vine, some of which would take years to mature? The increased value to property which trees and shrubbery add has become so evident that far sighted business men now plant trees and shrubs around

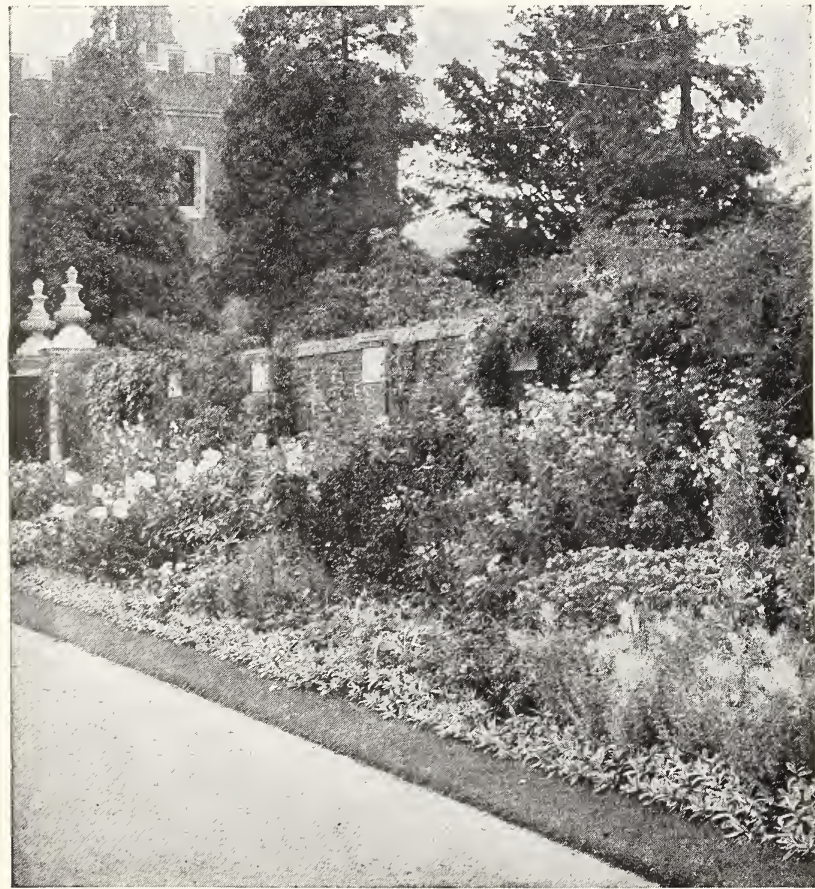

An Old-Fashioned Flower Garden. vacant lots that are intended for market, and have found that lots thus treated do not go begging.

\section{How to Plant}

In planting due regard should be paid to the space available, and trees and shrubs should not be planted at random. Nothing is more handsome than a fine, well cut lawn, with trees and shrubs planted along the drives leading to the house and other buildings. The background for a large lawn should be of the different varieties of larger growing trees, with groups of speci men trees in the foreground. Most shrubs are at their best planted in beds, either all of one variety or with several varieties so arranged that the higher growing ones will form the center with those of lower growing habits massed around them. These plants should be thoroughly cultivated and annually pruned. It is not well to plant so few that years must pass before a good effect is produced, but a surplus should be planted at first and this gradually taken out. Vines should be planted near the house and allowed to clamber on it or may be trained with fine effect over arbors or stakes placed in the lawn. 


\section{Deciduous Upright Ornamental Trees}

\section{ACER - Maple}

Trees of this group are hardy, vigorous, adaptable to many soils. For street planting they are unsurpassed, combining, as they do, attractive appearance with hardiness, rapidity of growth, comparative freedom from disease and injurious insects. They are well adapted for planting in avenues, and are largely used in general planting, either on large lawns or in small yards.

Ash Leaved (Negundo). (Box Elder). A native tree, well adapted to a great variety of soils and locations; hardy, a very rapid grower, and valuable where quick shade is desired.

Norway (Platanoides). The most popular species of the Maple group, either for the lawn or street planting. It forms a perfect, rounded head, with large, deep green foliage, is very hardy, easily transplanted, very compact in form, grows rapidly, and is exceptionally free from injurious insects.

Purple Leaved (Purpurea). One of the most beautiful and distinctly marked of all; leaves purplish red, particularly on the under side. A rapid, strong grower, hardy, and should be in every collection.

Schwedleri (Schwedler's Purple Leaved Maple). The Purple Norway Maple's beautiful leaves are especially fine in the Spring, when their gleaming red and purple contrasts brightly with the delicate green of the other trees. In midsummer they are purplish green, in Autumn golden yellow.

Silver Leaved or White (Dasycarpum). A North American species, of rapid growth, large size, and irregular rounded form, foliage bright green above and silvery white beneath; tree very hardy and easily transplanted.

Wier's Cut-Leaved Silver Maple (Wieri laciniatum). It is a variety of the Silver Leaved, and one of the most remarkable and beautiful trees, with cut or dissected foliage. Its growth is rapid, shoots slender and drooping.

\section{ESCULUS - Horse Chestnut}

Common or White Flowered (Hippocastanum). A very beautiful, well known tree, with round, dense head, dark green foliage, and an abundance of showy flowers in early Spring.

\section{AILANTHUS - Tree of Heaven}

Glandulosa. From Japan; a lofty rapid growing tree, with long, elegant feathery foliage, exempt from all disease and insects; one of the most distinct of ornamental trees with pinnate foliage.

\section{BETULA - Birch}

A genus of hardy trees, some of which are natives of the United States. They are rapid in growth, graceful in form and well adapted for landscape work, either in groups or avenues.

Alba (White Birch). This is the common Birch of Europe, with silvery white bark, small, smooth leaves, and a pleasing drooping habit.

Purpurea (Purple Leaved Birch). The leaves are a bright color in the Spring, but fade during the Summer to a dull green.

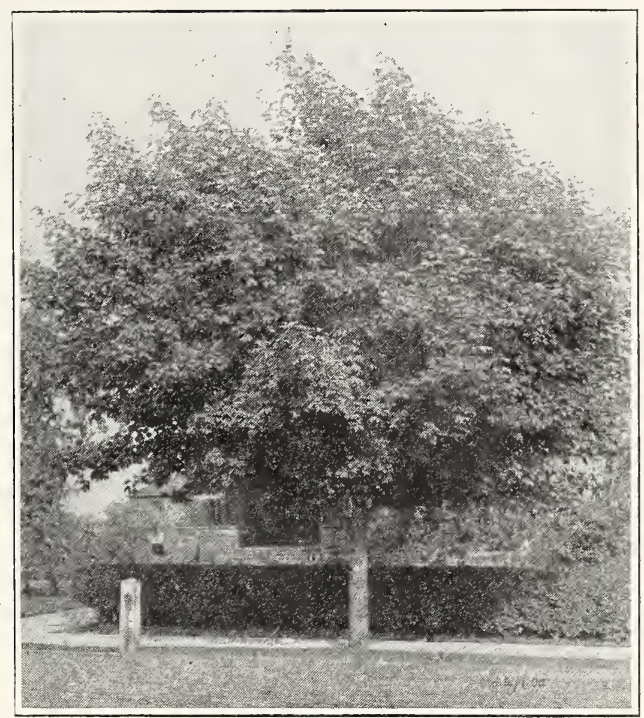

Norway Maple.

CATALPA - Indian Bean, Etc.

A genus composed of about seven species, some of which are natives of this country. The large foliage and long panicles of beautiful white or mottled flowers, as well as their rapid growth, have caused them to be very popular with planters. Suitable for low grounds.

Bungei (Chinese Catalpa). A curious dwarf form that grows only three or four feet high and twice as broad, forming a pretty domeshaped head of great, soft, leathery leaves.

Speciosa. A Western species growing to a large size, and with faintly mottled flowers, in large, showy clusters, followed by curious long beans that give the tree a most pictuesque aspect in Winter.

\section{CORNUS - Dogwood}

White Flowering Dogwood (Florida). A beautiful native tree, flowering after the redbuds when most other trees are still bare. The great white flowers are 3 inches and more in diameter, lasting, in favorable weather, several weeks.

Red Flowering (Rubicunda). Red flowers, very showy. The leaves are darker than the White Flowering. Blooms late in May just after the White Flowering. A slow, rather crooked grower.

\section{CRATAGUS - Thorn}

The Thorn justly deserves to be classed among the most beautiful trees, for small yards and for grouping anywhere. They are very hardy and grow well in all dry soils. The flowers are showy an̂d abundant, often quite fragrant; the fruits are retained long in some species; are so thick as to burden the branches and frequently of bright colors.

Hawthorn, Common English (Oxyacantha). A shrub or tree of twenty feet. Single white flowers. Good for defensive hedges.

Paul's Double Scarlet Thorn (Coccinea flore pleno). Of quick growth, showy, new and perhaps the best sort. Flowers are in clusters, very double, large and full, and a deep rich crimson. 


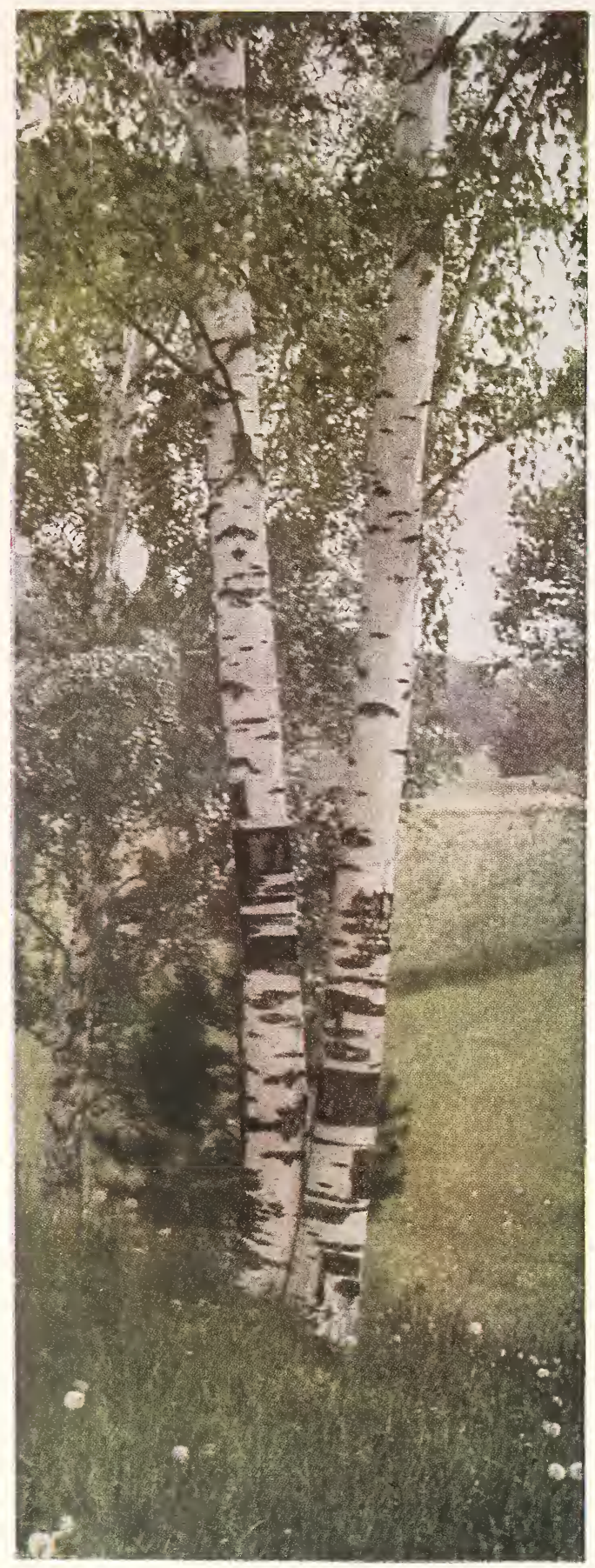

Birch.

DECIDUOUS TREES-Continued.

FRAXINUS - Ash

American White (Americana). Our forest tree, tallest of the species, with straight, clean trunk, smooth, gray bark and glossy leaves. Useful for parks, streets or large grounds.

\section{FAGUS - Beech}

The Beeches, especially the different varieties of F. sylvatica, are of the greatest use in landscape gardening. They are all hardy and love a deep, rich soil to develop their greatest beauty. Mostly of large size, but not very rapid in growth.

Purple Leaved Beech (var. purpurea). An indispensable ornament for every lawn. The rich purple foliage is so decided and beautiful that no other tree is better adapted for notable and charming contrasts in grouping.

\section{GYMNOCLADUS - Kentucky Coffee Tree}

A picturesque irregular tree, with peculiarly rough-barked twigless branches and broad fronds of twice-pinnate foliage of a bluish green. Bears long racemes of white flowers in early Summer. Foliage turns yellow in the Fall.

\section{LIRIODENDRON - Tulip Tree}

A tall, magnificent native, of rapid, pyramidal growth. Its smooth, erect gray bole rises to a great height, and is clothed with a splendid vesture of large, odd-shaped, glossy leaves and sprangled in spring with large, tulipshaped flowers of greenish yellow and orange. One of our most distinguished tall trees for broad avenues, parks and lawns.

\section{PERSICA - Peach}

Purple or Blood Leaved. The young leaves are as red as blood, but gradually change to bronze or green. A very effective foliage plant in early Summer.

Rose Flowering Double (Rosea fl. pl.) A small sized tree with beautiful delicate rose colored flowers. Blooms in May. When fully grown, eight to ten feet high.

\section{PRUNUS - Plum}

Purple Leaved Plum (Prunus Pissardi). A distinct and handsome little tree, covered with a mass of small, white, single flowers in Spring, later with showy pinkish purple leaves that deepen in color to the end of the season.

Double Flowering Plum (Triloba). A very hardy and beautiful tree or shrub covered in early Spring with a profusion of double pink flowers an inch in diameter.

\section{POPULUS - Poplar}

Poplars are more easily and quickly grown than almost any other trees and thrive in nearly all soils. Their leaves are bright and their tops thin, fitting them better for use in composition than as specimen trees. However, where immediately shade is desired, they can be planted with slower growing, more permanent trees among them, and when the latter are large enough the Poplars may be cut away, if unsatisfact ory

Carolina Poplar (Monilifera). Unexcelled for quick growth and effect, its rapid growth giving an air of luxuriance to places where other trees appear starved.

Lombardy or Italian Poplar (Fastigiata), of obelisk form, growing rapidly to extravagant heights. Leaves glossy green above, silvery beneath. One of the characteristic trees of Lombardy and otrier parts of Italy.

\section{PYRUS - Flowering Crab}

Handsome small trees, literally covered in the Spring with showy, sweet scented flowers. They are very hardy and thrive in almost any kind of soil. As specimen trees for garden and lawn they are both ornamental and desirable. Bechtel's Donble Flowering. This Crab is the finest acquisition in the way of a flowering shrub that has been introduced in recent years. Tree sturdy, hardy, and free from disease, medium size, and when in bloom presents the appearance of being covered with rery delicate pink roses. 


\section{DECIDUOUS TREES-Continued.}

QUERCUS - Oak

The Oak is in demand for use as lawn and street trees, being the most majestic of deciduous forest trees, almost without exception, very long-lived. Although their growth at first is slow, if planted in good soil will out-grow many other trees. Oaks hold their leaves late usually and the Autumn hues are very brilliant and lasting.

Red Oak (Rubra). A broad tree of rapid growth; large rich foliage, which turns to a bronzy red in the Fall. A deservedly popular tree.

Scarlet Oak (Coccinea). A grand, round-topped tree, with bright green, deeply cut leaves that color to sparkling red in the Fall. Grows well in dry situations.

\section{SALISBURIA}

This species, the only representative of its genus, is of great antiguity. Does best in moist, loamy soil.

Ginkgo Tree or Maiden Hair (Adiantifolia) One of the most beautiful lawn trees. From Japan. Beautiful, rich, glossy fernlike foliage. Rapid growth. Rare and elegant. A tall, upright grower.

\section{SORBUS - Mountain Ash}

These are hardy ornamental trees with handsome foliage and showy red fruit. They thrive in moist, loamy soils and are particularly valuable as specimen trees for the lawn. The fruits are eagerly sought by birds, and a few trees near the house will give bird lovers much pleasure in early Autumn.

European (Aucuparia). A fine hardy tree: head dense and regular, covered from July till Winter with large clusters of bright scarlet berries. The foliage usually turns orange-red in the Fall.

Americall (Americana). A tree of coarser growth and foliage and brighter colored berries. Tall and broad-headed, handsome. hardy and quick growing. Very valuable in landscape work, for park, shade or street planting.

\section{SALIX - Willow}

Besides the beauty of their airy summer foliage, the Willows have a distinct value in the brightness of their bark when leaves have fallen. There are few trees that can be used to such advantage for cheery Winter effects. They grow fast and are adapted to a variety of soils and uses. Frequent cutting back gives a thicker growth of bright young twigs.

Golden Bark Willow (Vitellina aurea). A fine tree at all seasons, but very showy in the Winter months for its bright yellow bark. Grows to be a very large tree, 80 to 100 feet high, with a venerable appearance.

\section{TILIA - Linden; Basswood}

The Lindens grow fast, forming noble trees of rounded outline, and casting a dense, cool shade. The leaves are large and cordate, the flowers light yellow, exhaling a delightful citron odor. All are among our best large growing street and avenue trees, fine also for specimens and grouping.

American or Basswood (Americana). Grows fast, forming a large, upright, spreading tree. Leaves are large and cordate, flower light yellow, delightful citron odor. Fine for the street and avenue, also for the lawn.

\section{ULMUS - EIm}

The Elm is one of the historic trees of this country, and famous old trees are guarded carefully against destruction, either through old age or accident. For street and park planting there is no finer tree than the grand American FIm of our forests. There are also foreign varieties of great value for specimen trees.

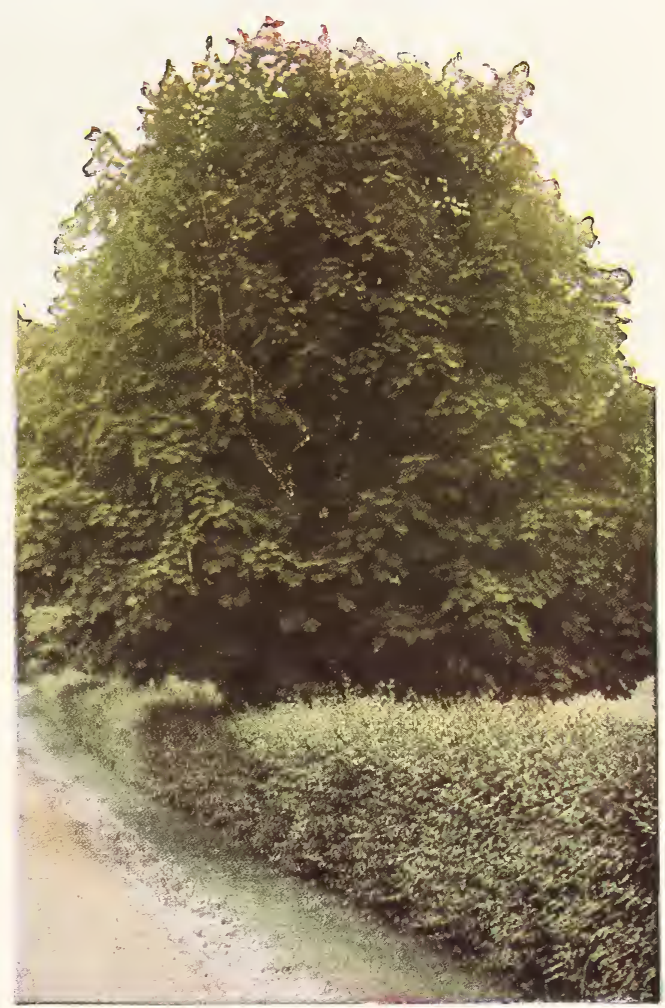

Ligustrum-Privet.

American Elm (Americana). A magnificent stately tree, easily distinguished by its wide, weeping top and pendulous branchlets. One of the most noble and graceful trees where a tall. spreading tree is desired.

Purple Leaved (Purpurea). A beautiful and distinct variety; leaves of rich purple when young. When fully grown, fifteen to twenty feet high

\section{Weeping Deciduous Trees}

\section{BETULA - Birch}

Cut Leaved Weeping (Pendula laciniata). Beyond question one of the most popular of all weeping or pendulous trees. Tall, slender, yet vigorous growth, graceful, drooping branches, silvery white bark and delicately cut foliage.

\section{MORUS - Mulberry}

Teas' Weeping Mulberry (Morus pendula). One of the finest and most graceful weeping trees, forming an umbrella-shaped head, with slender, willowy branches drooping to the ground. Tree perfectly hardy, enduring the severe cold of the North, and extreme heat of the South.

\section{SALIX - Willow}

Wisconsin Weeping Willow (Dolorosa). Of drooping habit and hardier than Babylonica. Valuable on account of its ability to resist severe cold. The best weeping Willow.

\section{ULMUS - Elm}

Camperdown Weeping Elm (Scabra pendula) of fine and notable habit, the strong, stout branches often sweeping out horizontally for several feet before they curve downward, making a broad, handsome head. Trees, when delivered, are from five to eight feet tall and trunk grows practically no taller. 


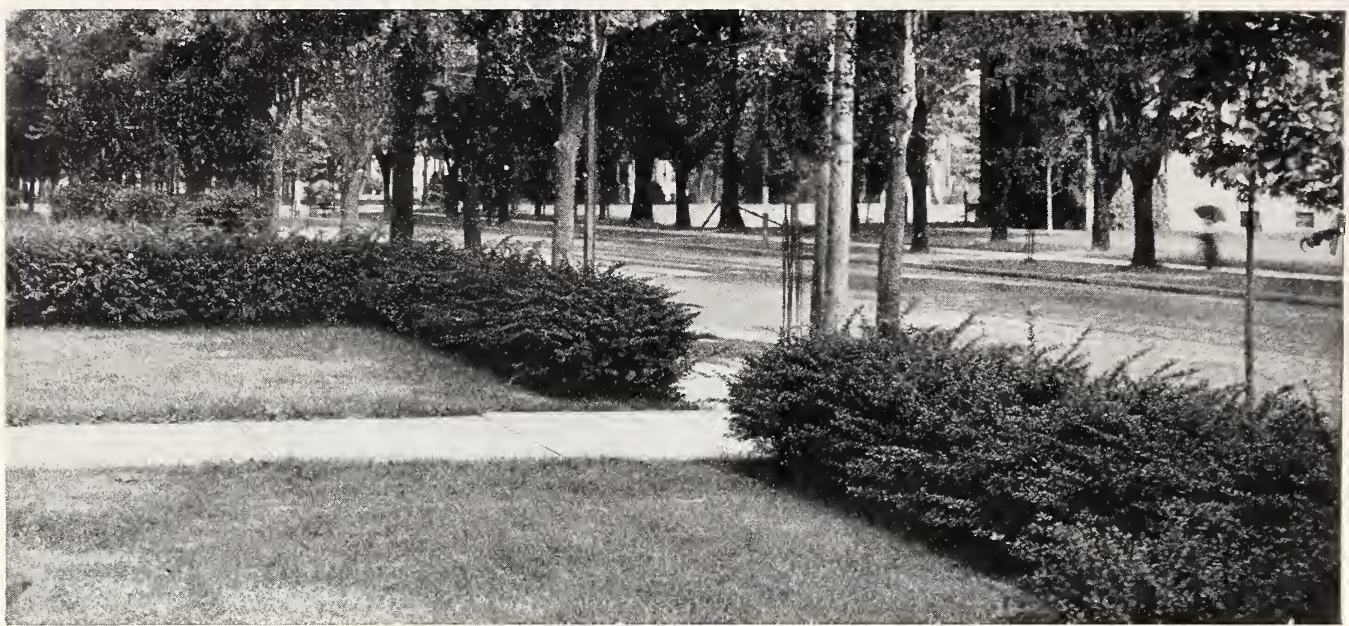

Barberry Hedge.

\section{Hardy Deciduous Shrubs}

Until seen, one cannot appreciate the effect that can be brought out by properly arranging and grouping the wonderful assortment of foliage, ranging in color from the darkest green and purple to light orange and silver tints. For hədges, and for giving privacy to home grounds, they are indispensable; and if selected with reference to period of blooming, it is possible to have flowers continuously from April to November. No yard is complete without one or more beautiful flowering shrubs.

\section{ALTHEA FRUTEX OF ROSE OF SHARON} (Hibiscus Syriacus)

The Altheas bloom late in the Summer, about August and September; they are very hardy, easily cultivated and will bloom until their growth is cut off by frost; they are fine for flowering hedges, and will stand considerable pruning. This should be given in Winter. They attain a height of from six to ten feet.

Double Variegated

Double Blue

Double Variegated

Double White

Leaved

Double Purple

Double Red

Double Pink

AMYGDALUS - Flowering Almond

Double Rose Flowering. A beautiful small shrub, producing in May, before the leaves appear, small double roselike flowers, closely set on the branches.

Double White Flowering. A pretty sort, of small size, producing beautiful white flowers in May.

\section{BERBERIS - Barberp}

The Barberries are neat, dense growing shrubs, and are beautiful at all seasons. The masses of white, yellow or orange blossoms are shown in Spring: their leaves color brightly in the Fall; their scarlet, blue or black berries are persistent through most of the Winter; they are used for hedges, borders around other flowering shrubs or individual beds.

Thunbergi (Thunberg's Barberry). Inimitably neat and dense in growth, yet quite graceful because of its drooping branches. The yel low flowers are followed by scarlet fruits, persistent through most of the Winter: the leaves color to scarlet and gold in Autumn. BUDDLEIA - Butterfly Bush

Variabilis (Sweet Scented Buddleia) 4 feet. A newly introduced and very handsome species with showy, fragrant lilac and orange-yellow flowers.

CALYCANTHUS - Carolina Allspice

Floridus (Sweet Scented Shrub). An interesting shrub, having rare and peculiar fragrance of wood and flowers; blooms abundantly, of a peculiar chocolate color.

\section{CHIONANTHUS - White Fringe}

Virginica. One of the most beautiful wild shrubs, growing to treelike proportions in favorable locations. Its loose, gracefully drooping panicles of white flowers are fragrant, and borne in fringing clusters above very large, deep green leaves of thick, leathery texture.

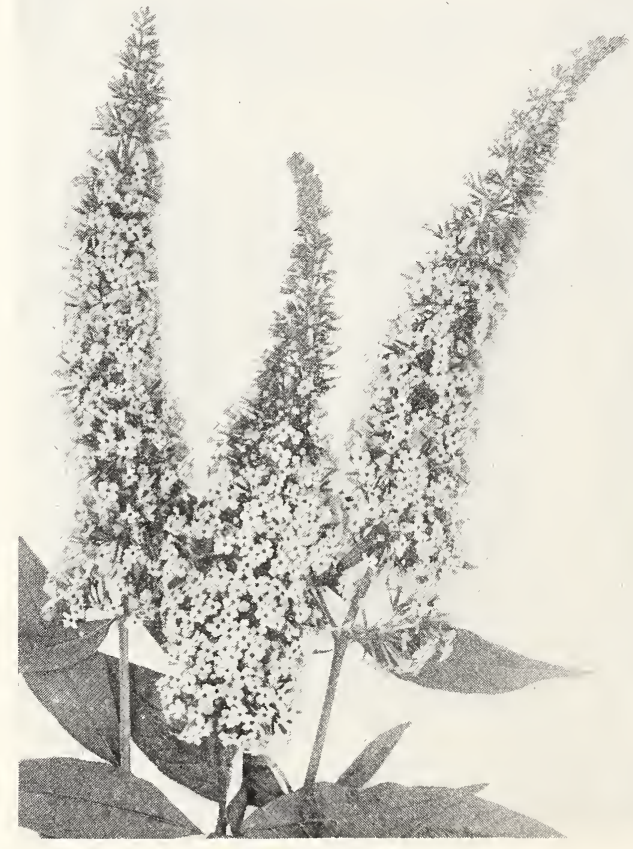

Buddleia-Butterfy Bush. 


\section{SHRUBS-Continued.}

CORCHORUS - Kerria or Globe Flower

Japonica. This fine shrub is of a spreading habit, with slender green branches and globular, yellow flowers.

Variegata (Variegated Kerria). This variety makes dwarf, twiggy growth, has white and green variegated leaves, and bears single, pale lemon flowers.

\section{CORNUS - Dogwood}

The Dogwoods of tall growth and bearing large flowers, are described under Deciduous Trees, The shrubbery Dogwoods, in many cases have very pretty flowers, but are valued also for their handsome fruits, leaf variegation and bright colored bark. If planted in lines or groups against evergreens the bark is very showy in Winter, especially if pruned yearly to make the growth of young shoots thicker.

Alternifolia (Alternate Leaved Dogwood). Flowers creamy white, in large bunches; very fragrant; followed by blue berries in the Fall. Foliage large, distinct and curious in habit of growth.

Sibirica (Red Siberian Dogwood). A rare and remarkable variety, with bright red bark in Winter

\section{CYDONIA - Japan Quince}

Japonica (Pyrus Japonica). A very hardy shrub, with double crimson flowers in profusion early in the Spring. Highly ornamental.

\section{DEUTZIA}

One of the most desirable shrubs to plant as individual specimens, or for grouping. Their hardiness, luxuriant foliage and profusion of attractive flowers render them deservedly among the most popular of flowering shrubs. The flowers are produced in June, in racemes four to six inches long. They are extremely floriferous and ornamental, and make possible many striking effects in garden or border plantations. Of easy culture, thriving in almost any well drained soil.

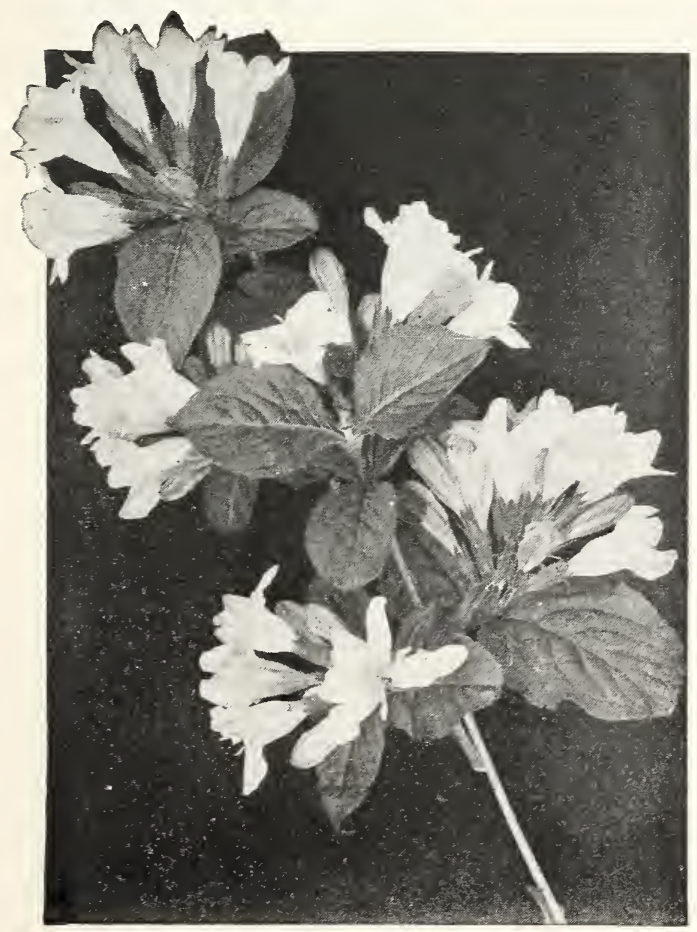

Weigela Rosea.

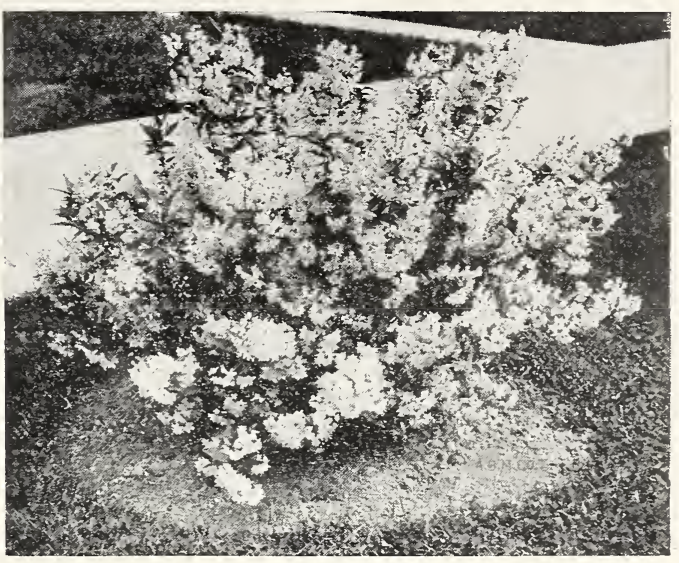

Deutzia Gracilis.

Crenata (Crenate Leaved Deutzia). One of the best of hardy shrubs, bearing in June a great profusion of single white flowers on long slender branches.

Double Flowered Pink Deutzia. So named on account of the distinct pink or reddish stripes on the petals of the flowers. The bloom is perfectly double, resembling little rosettes.

Candidissima (Double White Flowering Deutzia). This extremely beautiful double form has snow-white flowers and blooms in greatest profusion.

Pride of Rochester. A valuable form originated at Rochester, New York. It is rather earlier in flowering than the others; double white, with a tint of rose on the back of the petals.

Gracilis (Slender Branched Deutzia). One of the most valuable shrubs in the entire list, for all purposes. It is entirely hardy and forms a small round plant, blooming freely in early June. Pure white.

Lemoinei. An elegant new hybrid of $D$ Gracilis, as dwarf and free-flowering, but carrying its pure white, widely opened flowers in erect panicles.

\section{DIERVILLA - Weigela}

A group of very beautiful shrubs, easily grown and always in demand. They were introduced from Japan and are entirely hardy with us. We adhere to the correct classification of Diervilla, although the genus is popularly known as Weigela.

Candida. It is of vigorous habit, and an erect grower, becoming in time a large sized shrub. Flowers pure white and produced in great profusion in June, and the plants continue to bloom during the Summer.

Eva Rathke. A new and exceedingly showy variety, with bright red flowers borne freely during early Summer. It is very distinct and decidedly the best of its color. Rather slender in growth, with villous foliage.

Floribunda. A large, fine bush, 6 to 8 feet tall, bright with crimson flowers that are small and cinnabar-red in the bud. Blooms in June and is very floriferous.

Rose Colored (Rosea). An elegant shrub, with fine rose colored flowers, introduced from China by Mr. Fortune. Of erect, compact growth; blossoms in June.

Variegated (Nana variegata). This is perhaps second to no other hard-wooded plant with variously colored leaves. It stands the sun well and retains its well marked tints until Autumn. The flowers are lighter in color than the Rosea, but it is equallv as froe in bloom. 


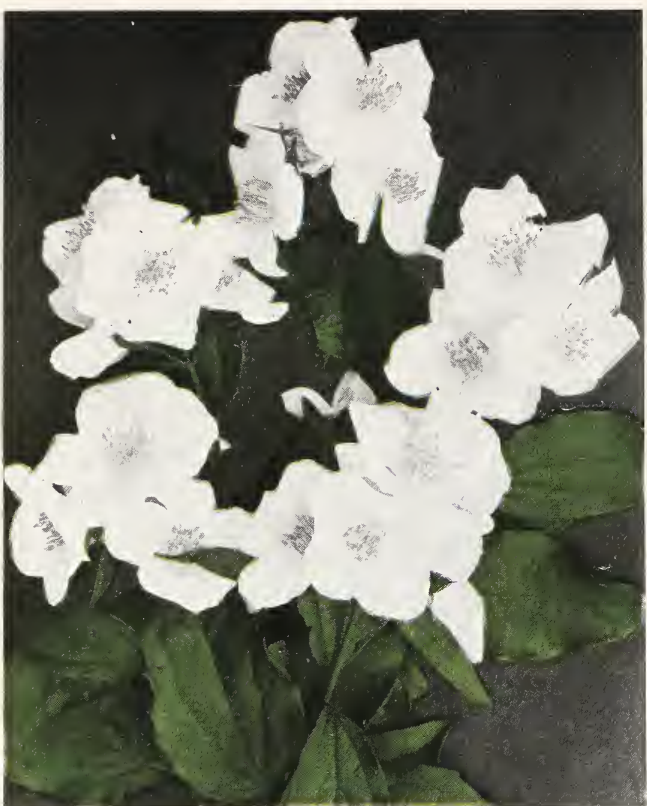

Philadeiphus-Mock Orange.
Amurense (Amoor River Privet). Hardier than others, growing 8 to 12 feet high, with dark green leaves, which persist almost through the Winter. Evergreen in the South. Bears erect panicles of handsome white flowers in June, followed by black berries. The best for hedges.

Ibota (Chinese Privet). Very vigorous, has distinct, deep green leaves and numerous racemes of pure white, fragrant flowers.

Ovalifolium (California Privet). A species of unusual beauty that has become the most popular of all hedge plants. Its shining leaves give it value for porch and terrace decoration when grown in standard form. Can be sheared to any desirable form.

\section{IONICERA - Bush Honeysuckle}

The Bush Honeysuckles form pretty, softleaved shrubs with delicate, fragrant flowers of characteristic odor. The colored berries in late Fall add another attraction. Hardy and thrive easily.

Pink Tartarian. A beautiful shrub, producing large bright pink flowers, striped with white, in June.

Red Tartarian (Tatarica rubra). A well known sort. Blooms in May. Bright red flowers and followed with showy fruit.

White Tartarian. Forms an upright bush with white flowers, which are followed with yellow fruit.

EUONYMUS - Strawberry or Spindle Tree

Alatus (Winged Burning Bush). Corky winged branches; a fine shrub of solitary planting as well as for massing, the rich red and crimson of its leaves being very showy in Autumn. 8 to 10 feet

Imerican. A beautiful large shrub, or small tree. Its glowing crimson fruit makes it very attractive.

\section{FORSYTHIA - Golden Bell}

A valuable genus of shrubs from China and Japan, blooming very early in Spring. Flowers yellow, drooping, borne in great profusion. Entirely hardy here and of the easiest culture.

Fortunei. A strong growing species, with stout, erect branches and rich green foliage, blooming in April and continuing for some time. It is a conspicuous object in the shrubbery.

\section{HYDRANGEA}

The native species are handsome shrubs of medium size, with fine large leaves, and generally of light green color, and perfectly hardy. The Hydrangea Hortensia requires protection in Winter, and they should be grown in pots or boxes, wintered in the cellar, and in Summer placed along walks in prace of shade trees.

Arborescens sterilis (Hills of Snow). Flowers raylike and sterile, resembling a snowball. A very handsome, floriferous, hardy shrub, literally loaded with white flowers, and continuing to bloom most of the summer.

Hortensia (Changeable). Flower-heads large and showy, with a pretty pink tint which changes to blue when iron filings or swamp-muck are mixed with the soil.

Paniculata grandiflora. Familiar to almost everyone as the most conspicuous shrub, attaining a height of six $t$ ten feet, strictly hardy; flowers produced in great panicles are at first pure white, then changing to pink, beginning to bloom early in August, continuing several weeks.

Hydrangea Tree, paniculata grandiflora. The same as above, grown on stems from three to five feet high. This is most attractive and desirable.

\section{LIGUSTRUM - Privet}

A rapid grower in most situations; does well in partial shade. Excellent for hedges, or for association with other shrubs. It is almost an evergreen and grows freely in all soils; is compact and regular in its form and bears shearing to any extent. Their white flowers grow in sprays, are fragrant, and followed by berries of different colors.

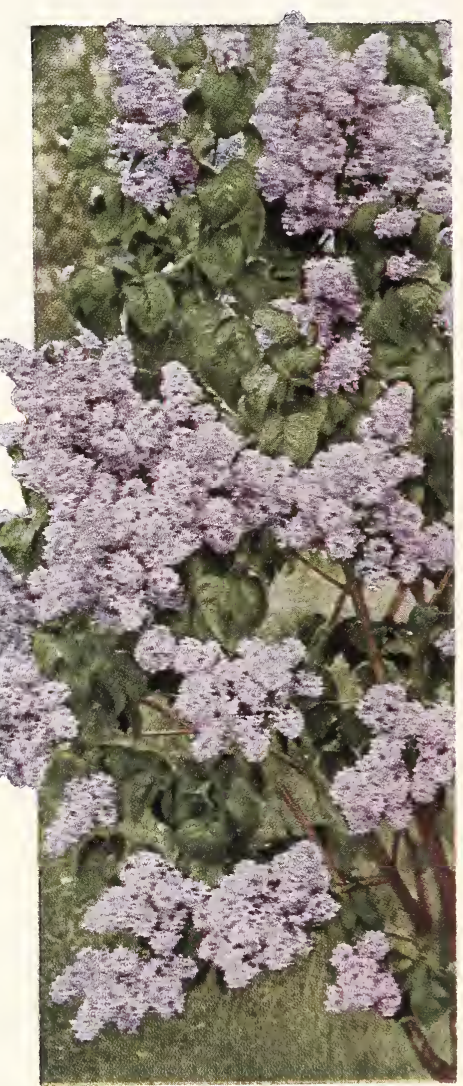

Purple Lilac. 
SHRUBS-Continued.

PHILADELPHCS - Syringa or Mock Orange

The shrubs are usually tall, vigorous growers, with large foliage and flowers, alid so are valuable for backgrounds, screens, groupins and specimens. The flowers are milkwhite, in most cases, and beautiful for cuting.

Coronarius (Garland Syrin ga). A fine old form that blooms among the earliest and in very graceful sprays. Its large snowy flowers are delightfully scented.

Aurea (Golden Syringa). A very pretty shrub of medium size, with golden yellow foliage. It retains its color through the entire season, and creates a pleasing and striking effect, planted in groups with other shrubs.

Flore pleno (Double Flowering Syringa). Habit strong, dwarf growing, with semi-double white flowers.

Graudiflorus. The most vigorous species of the group. Its long, irregular branches are clustered with large, slightly fragrant flowers in Jurie.

Lemoinei (Boule d'Argent). Of dwarf, compact habit; flowers large and fine; semi-double.

\section{RIBES - Currant}

Aurea (Golden Currant). Bush with glossy green foliage, which assumes bright Autumn tints. In May bears fragrant yellow flowers, followed by dark brown fruit.

Sanguineum (Red Flowering Currant). Shrub of fine habit, with handsome foliage, producing long, pendulous racemes of deep red flowers in July.

\section{SAMBUCUS - Elder}

Although these shrubs are attractive in flower and fruit, they are grown chiefly for their beautiful leaves; they grow well in all soils and must have vigorous pruning to keep them in shape.

Aurea (Golden Elder). A handsome variety, with golden yellow foliage. A valuable plant for enlivening shrubberies.

Variegata (Variegated Leaf Elder). Of strong, healthy growth; foliage mottled with yellow and white. One of the best variegatedleaved shrubs.

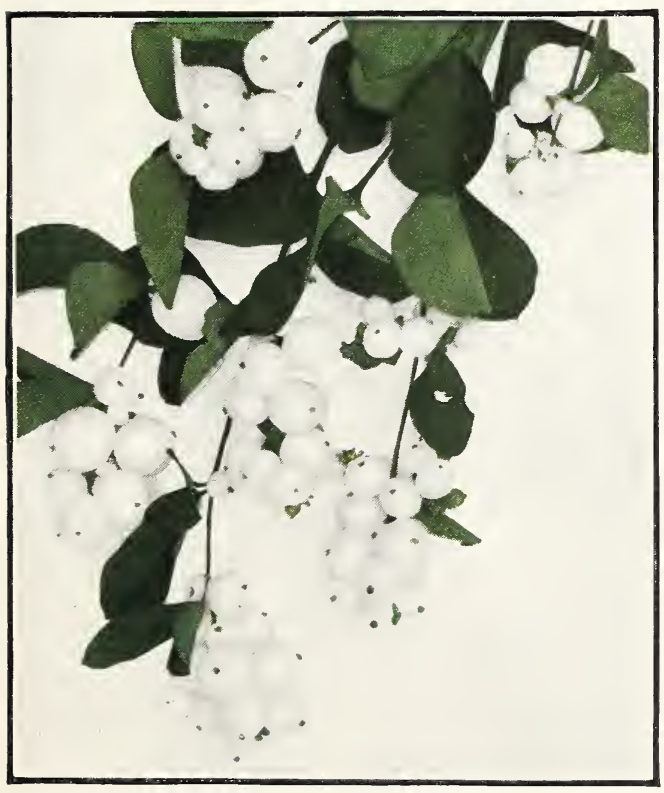

Symphoricarpos-Snowberry.
Viburnum Plicatum-Japan snowball.

\section{SPIRAEA - Meadow Sweet}

All the Spiraeas bloom extravagantly, which makes them decidedly striking. A good collection of them will give flowers the entire season. All the species are very hardy, easily grown, and will be found useful for specimens, groups, screens, borders, ornamental hedges, etc.

Anthony Waterer. Makes a low, compact bush, covered nearly the whole season with umbels of deep crimson flowers. Desirable for massing or bedding, as well as for single specimens.

Billiardi (Billiard's Spiraea). Rose colored: blooms nearly all Summer.

Callosa alba. New, has heads of pure white flowers, very delicate and beautiful. Keeps in flower all Summer; valuable small shrub.

Opulifolia aurea (Golden Leaved). Of similar habit. The leaves are bright yellow in the Spring, gradually changing to golden bronze in the Fall.

Thunbergi ('Thunberg's Spiraea). Feathery masses of pure white flowers in early spring in Autumn its leaves change to bright red and orange. Dwarf habit; rounded and graceful form; branches slender and drooping.

Van Houttei. Without doubt the finest variety in the collection. At the flowering season in May and early June, the plant is covered with a mass of large white flowers, presenting a beautiful appearance. Very hardy. One of the finest shrubs under cultivation. 


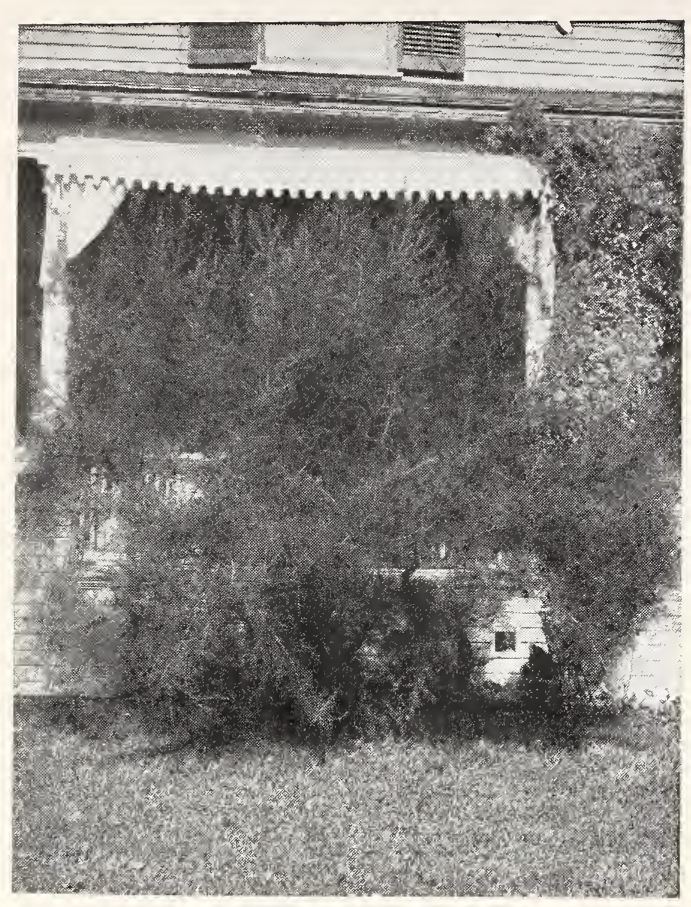

Tamarix-Tama:isk.

\section{SHIRUBS-Continued.}

\section{SYMPHORICARPOS}

These shrubs are valued for their bright, persistent fruits, and for use as undergrowths in densely shaded places, where little else will grow. The two species below are of slender, medium growth, and will flourish under trees, or in any soil.

Racemosus. Inconspicuous, rose colored flowers in June and July, followed by large, clustered, milk-white fruits which remain far into the Winter. The combination of pink flowers and white berries on the same twig is charming. Compact in form with numerous slender, twiggy branches. Can be used in either small group or in large mass and border plantings. Your landscape effect will be incomplete without a few of these artistic shrubs.

Vulgaris (Coralberry; Indian Currant). Like the Snowberry, except that its fruits are red, and cluster along the stems, which droop beneath their weight.

\section{SYRINGA - Lilac}

The Lilac appears to best advantage when massed in groups, and only a few varieties of but one or two colors. Moderately rich, moist soil suits them best. The dead flowers should be removed when the blooming season is over. as they give an untidy appearance; should not be pruned in Winter or Spring, as it destroys the flowers.

Persica var. alba (Persian White). Blossoms in long panicles, white, tinged with purple.

Vulgaris (Common or Old-Fashioned Lilac). The familiar species of all fine old gardens, with dense panicles of lilac flowers, still the most fragrant of any.
Villosa (Hairy Leaved Lilac). 6 feet. One of the newer species, quite distinct from the older Lilacs. Foliage large, not unlike that of the White Fringe. Flowers later than the others, rosy pink, and in large panicles.

Charles $\mathbf{x}$. Of exceptionally strong, rapid growth, with large, shining leaves and rather loose trusses of reddish purple flowers.

\section{NEW DOUBLE LILACS}

Jean Bart. Rosy carmine flowers in large, compact plumes.

Madame Lemoine. Superb white flower panicles. Fine and showy.

President Grevy. Flowers of a beautiful blue color, in huge panicles.

\section{TAMARIX - Tamarisk}

The Tamarisks are very hardy shrubs of strong growth, foliage light and feathery, their flowers delicate and fringing, usually in some light shade of red or pink. They will grow anywhere. Lately the variety $T$. Africana has been used for hedging and it is indeed very pretty for that purpose; if pruned several times during the season it is even finer than the best of evergreen hedges, and from a distance is frequently taken for such.

Africana. A tall, graceful shrub, with small foliage like a Juniper, and delicate, small, rosy purple flowers, produced in spikes; very pretty.

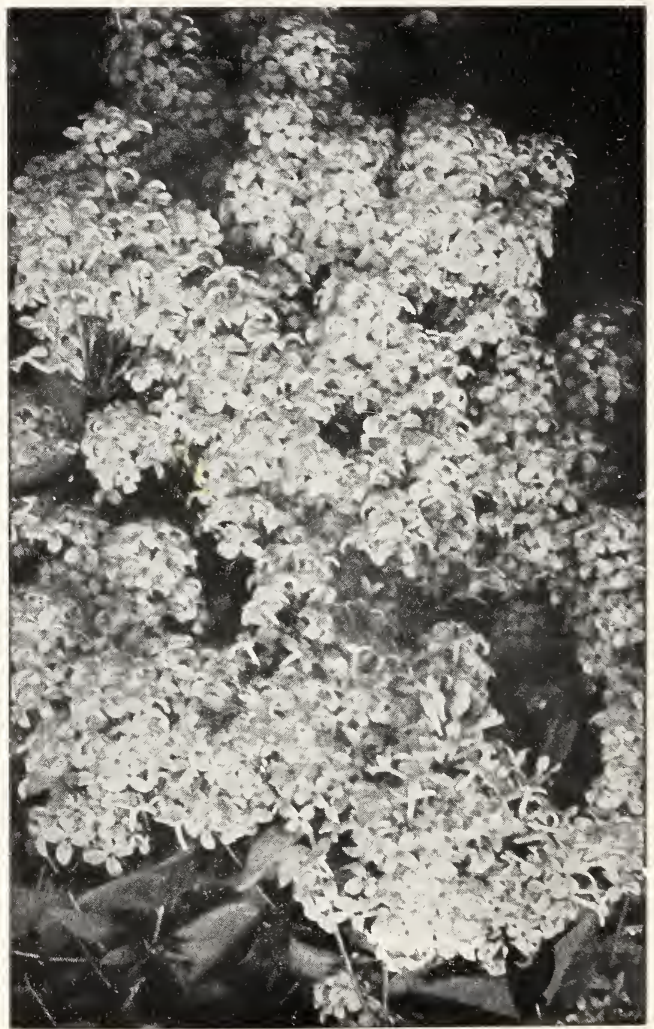

Syringa-Lilae. 


\section{SHRUBS-Continued.}

VIBURNUM - Snowball

This is a showy group of shrubs that usually grow from five to ten feet high, bloom lavishly in the Spring, bear pretty fruits and color to red or purple in the Fall.

Opulus (High Bush Cranberry). 6 feet. An attractive and showy shrub at all times, and particularly in the Fall, when covered; with its large red berries.

var. sterile (Common Snowball). A well known favorite shrub of lárge size, with globular clusters of pure white flowers the latter part of May.

Tomentosum (Single Japan Snowball). 6 feet. Brown branches and beautifully ribbed foliage, green above and bronzy purple beneath. White flowers, succeeded in late Summer by scarlet berries, turning to a blue-black.

Plicatum (Japan Snowball). 6 feet. Of upright, bushy growth, entirely dark green leaves, and large heads of enduring white flowers; superior to the common sort.

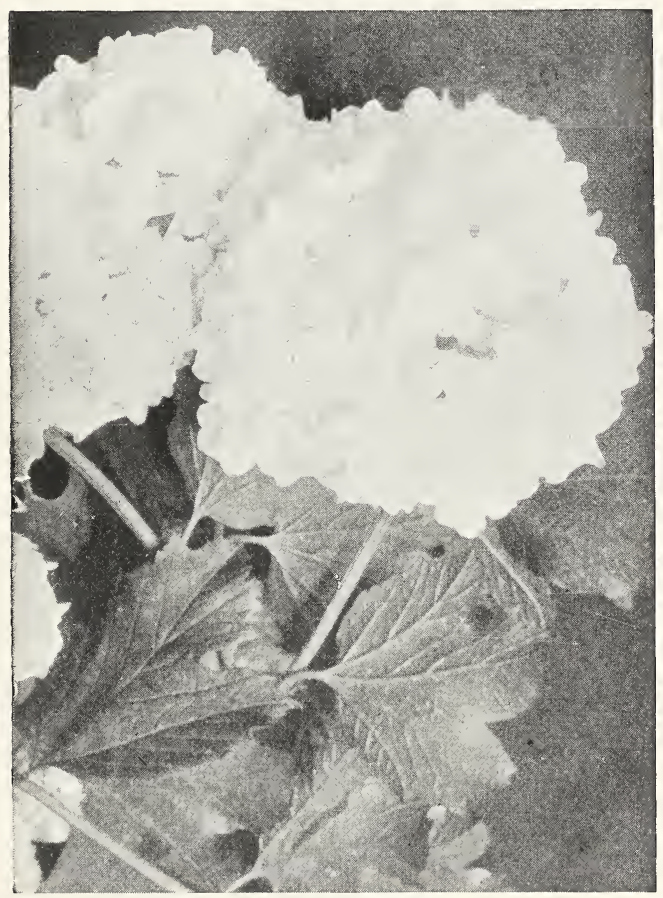

Viburnum Cpulus Sterile-Snowball.

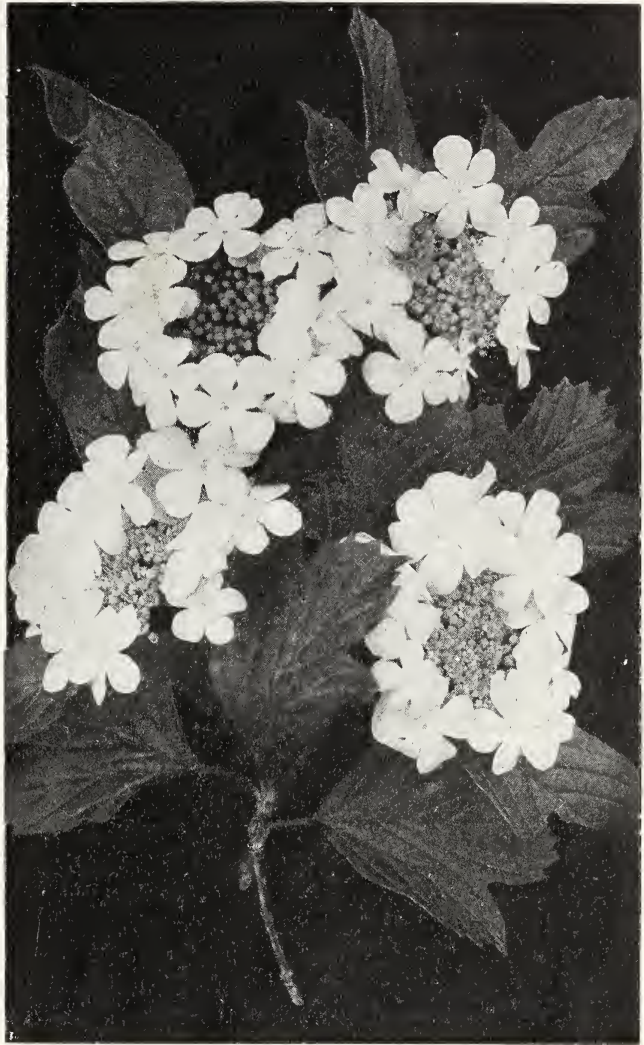

Viburnum Opnlus-High Bush Cranberry.

\section{Shrubs for Shady Situations}

\section{BERBERIS (Barberry). In variety.}

CLETHRA alnifolia (Sweet Pepper Bush).

CORNUS (Red Branched Dogwood).

- stolonifera (Red Osier).

DIERVILLA (Weigela). In variety.

FORSYTHIA viridissima.

LIGUSTRUM (Privet). In variety.

LONICERA fragrantissima (Fragrant Bush

Honeysuckle).

RHUS aromatica (Fragrant Sumach).

STMPHORICARPOS racemosus (Snowberry).

- vulgaris (Red-Fruited Snowberry).

VIBURNUM acerifolium (Arrow Wood)

-dentatum (Arrow Wood).

-lentago (Sheep Berry).

-tomentosim.

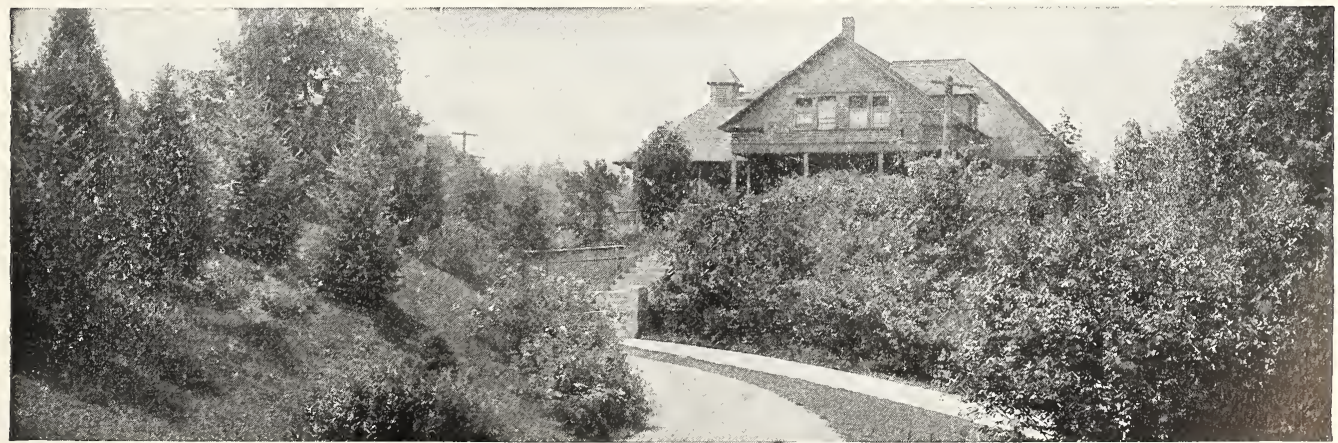




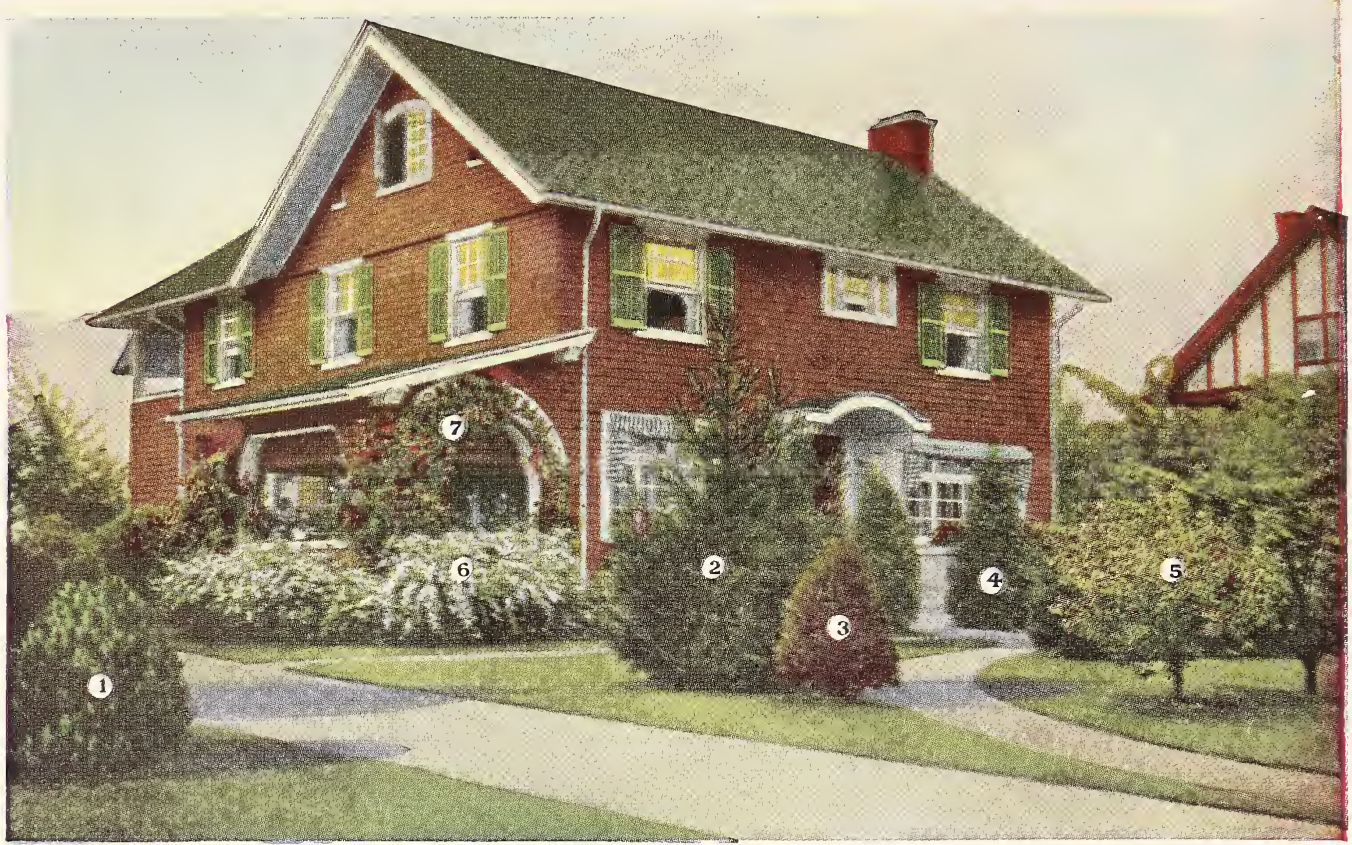

No. 1-Hugho Pine. No. 2-Norway Spruce. No. 3-Golden Arbor-Vitae. No. 4-Concolor Fir. No. 5-Bechtel's Flowering Crab. No. 6-Spicea Van Houttei. No. F-Crimson Rambler.

\section{Evergreens}

Evergreens are beautiful all the year and form grand specimens in time. We strongiy recommend our customers to plant more largely of the hardy sorts. They are of special value for screens, hedges and windbreaks; they should never he set in the Fall except in the South, and great care must be taken to avoid all exposure to sun and wind. In the following list we confine vurselves strictly to perfectly hardy species and varieties, such as are most useful for general planting. In transplanting evergreens, so much depends upon the care of the planter in protecting roots from the air and sun, that we cannot guarantee them further than that delivery shall be made in first class condition. We recommend spring planting for evergreens.

ABIES - Fir
Concolor (White Fir). A native species with long, broad foliage, bluish above and silvery beneath. Of all Fir trees, it best withstands heat and drought. Very hardy and grows rapidly; graceful and most desirable. Exceedingly rare.

\section{BIOTA - Chinese Arbor-Vitae}

Orientalis (Chinese Arbor-Vitae). 15 feet. The flat growth of the young branches and its bright green color make it interesting and valuable.

- aurea conspicua. Of compact, erect and symmetrical habit. Foliage intense gold, some of its branches being a solid metallic tint, others suffused with green.

- aurea pyramidalis. Of erect, symmetrical and compact growth. Of beautiful golden tint and columnar habit.

- pyramidalis (Chinese Pyramidal ArborVitae). Grows 10 feet high, light green foliage.

- compacta (Chinese Compact Arbor-Vitae). 5 feet. Of dark green color and rounding, compact habit of growth.

- elegantissima (Rollinson's Golden ArborVitae). 10 feet. Of upright, torchlike form. Foliage golden in Summer, bronze in Winter

\section{JUNIPERUS - Juniper}

Hibernica (Irish Juniper). Very erect and tapering in growth, forming a column of deep green foliage; a pretty little tree or shrub, and for its beauty and hardihood is a general favorite.

Virginiana var. glauca (Blue Virginian Cedar). One of the handsomest forms of these hardy evergreens. Foliage is distinctly silvery gray, holding its color throughout the year.

- var. variegata. Constant in its golden variegation; leaves finer than in the type. The three sorts form a handsome group.

\section{PICEA - Spruce}

Excelsa (Norway Spruce). A lofty tree, of perfect pyramidal form, remarkably elegant and rich, and as it gets age, has fine, graceful. pendulous branches; it is exceedingly picturesque and beautiful.

Pungens (Colorado Spruce). Perhaps the most attractive Conifer in our entire list of available species. It is entirely hardy, of comparatively rapid growth; has an elegant glaucous green tint, and a perfect outline.

Kosteriana (Koster's Blue Spruce). A selected strain of the bluest form from the Colorado Blue spruce. Very blue. 


\section{PINUS - Pine}

Austriaca (Austrian or Black Pine). A remarkably robust, hardy, spreading tree; leaves long, stiff and dark green; growth rapid.

Mugho (Dwarf Mugho Pine). A unique Alpine species, broader than its height and sometimes almost prostrate, forming a dark dome-shaped bush, 5 to 8 feet high. Used for planting on rocky banks, terrace slopes, small lawns, rockeries and near the sea.

Strobus (White Pine). The most ornamental of all our native pines; foliage light, delicate or silvery green; flourishes in the poorest soils.

\section{RETINISPORI - Japan Cypress}

Plumosa aurea (Golden Japan $\mathrm{Cy}$ press). One of the few really golden evergreens. The color of the young growth contrasts strongly with the darker shade of the other foliage. Striking and useful in many ways.

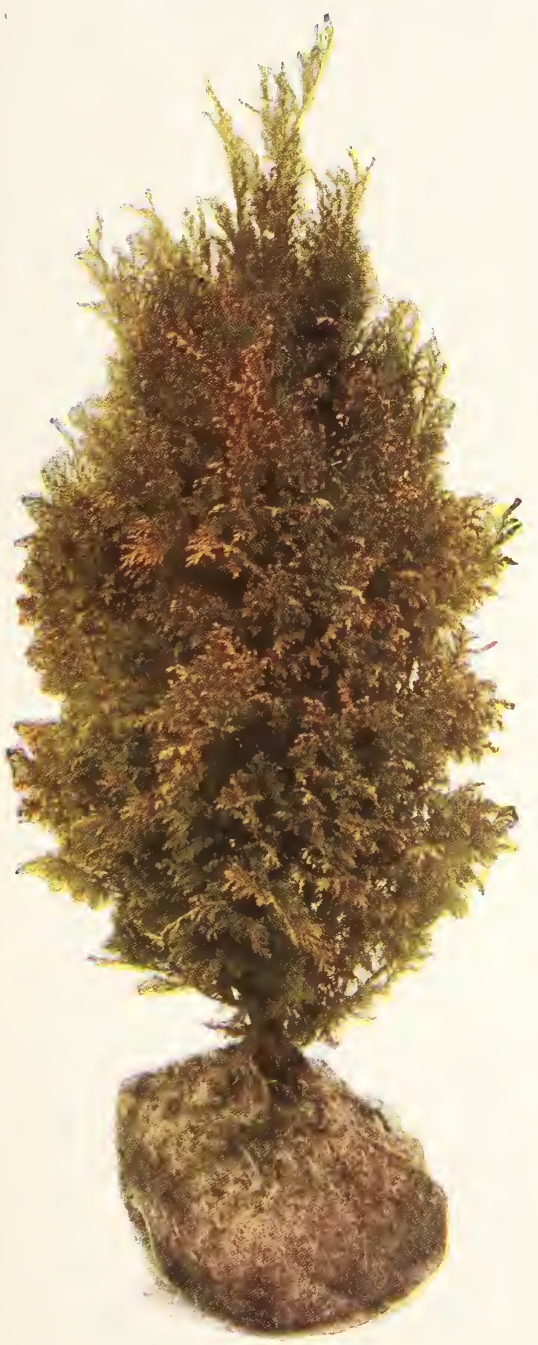

Retinispora.

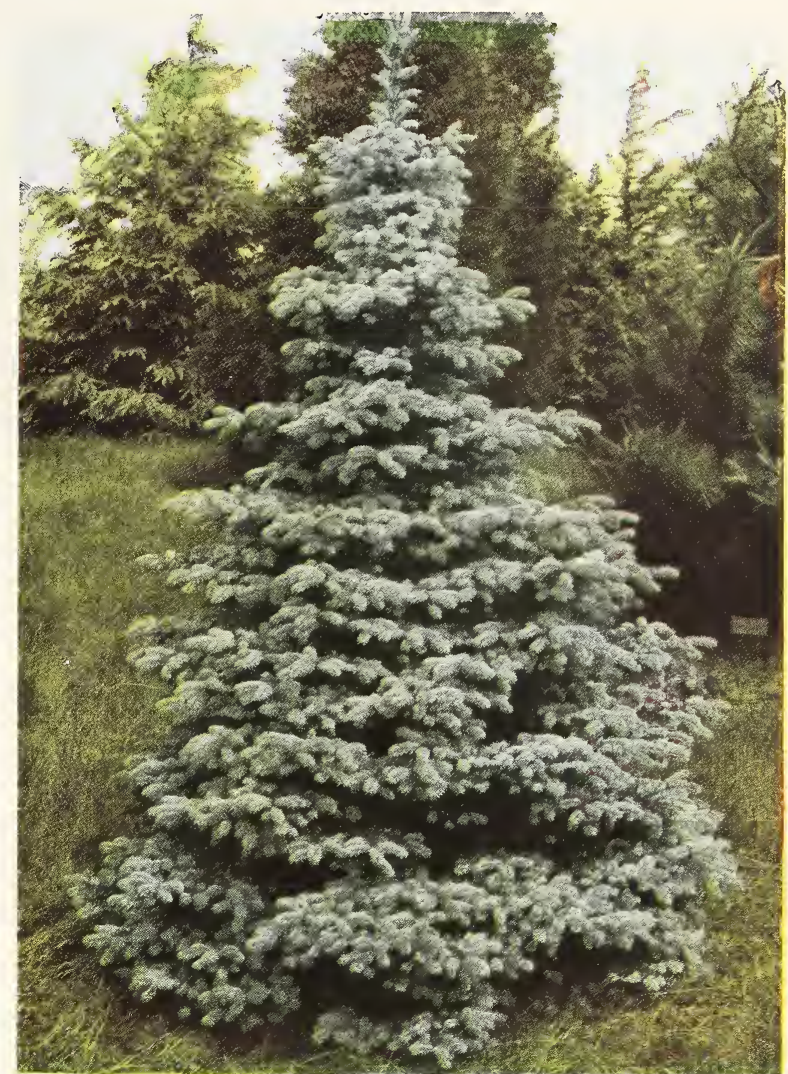

Colorado Blue Spruce.

\section{THUYA - Arbor-Vitae}

The Arbor-Vitae vary greatly in habit and color. They bear transplanting and pruning well and have many uses, especially in formal gardens. They are also well suited for bedding with other evergreens, for hedges, screens, shelter beds and house decoration. All are neat and symmetrical in habit, and are dense, bushy, with flattened, frondlike leaves.

Occidentalis (American Arbor-Vitae). A well known variety of great value; forms an upright, conical tree of only medium size, and is, all things considered, the finest evergreen for screens.

Compacta (Parsons' Compact Arbor-Vitae). Dwarf, dense habit; grows 3 to 4 feet high; one of the best for cemeteries; excellent for hedges.

Globosa (Globe Arbor-Vitae). Forms a natural evergreen globe or ball without any trimming; very pretty and hardy.

Pyramidalis (Pyramidal Arbor-Vitae). Very erect and regular, resembling the Irish Juniper; foliage a deep green color, well retained in Winter; perfectly hardy. Unlike the Juniper it is easily transplanted. One of the best.

Tom Thumb. A heath-leaved variety; hardier and lighter green than Ericoides. Has beautiful, soft, feathery, green foliage which changes to bronze in Winter. 


\section{Climbing Vines}

Vines are useful in many ways. They give quick results when planted on a new place, before trees and shrubs become established. For covering fences, rocks, walls, banks and trellises, they are peculiarly adapted. A porch without a vine is desolate and incomplete.

ARISTOLOCHA - Dutchman's Pipe

Sipho (Birthwort). A native species of climbing habit and rapid growth, with very large. heart-shaped leaves and curious pipe-shaped yellowish brown flowers.

\section{AMPELOPSIS}

Quinquefolia (American Ivy or Virginia Creeper). A very rapid growing vine covered with heavy digitate leaves affording shade and of great beauty when changing to scarlet in Autumn

Veitchi (Boston or Japan Ivy). The now famous Japan or Boston Ivy used so extensively to cover brick or stone buildings. The foliage is dense, completely carpeting a surface, and the autumnal tints of green and red are unsurpassed for reauty.

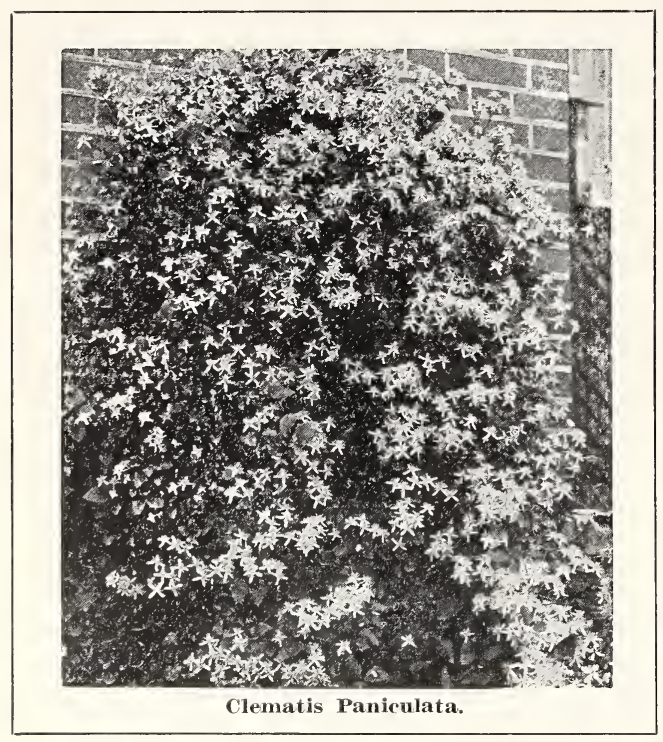

DIOSCOREA - Cinnamon Vine

Batatas. The Cinnamon Vine, most conspicuous in the Fall when small tubers cluster in the axils of its dark, glossy, arrow-shaped leaves. The white flowers are small, but fill the air with a delightful cinnamon odor.

\section{LONICERA - Honeysuckle}

var. Halliana (Hall's Japan Honeysuckle). Pure white and creamy yellow, very fragrant flowers; in bloom the whole season. Almost evergreen. Besides its ordinary uses as a climber, it is valuable for covering banks, bare places, etc., where grass will not grow.

\section{WISTARIA}

Multijuga. A Japanese species, with dark blue flowers, borne in racemes of astonishing length.

Sinensis (Chinese Wistaria). A most beautiful climber of rapid growth, producing long. pendulous clusters of pale blue flowers. When well established it makes an enormous growth.

var. alba. Differs from the Chinese only in having pure white flowers.

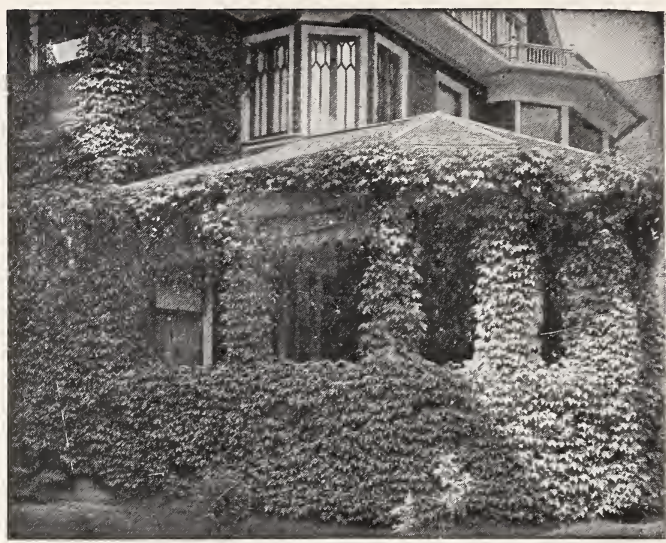

Boston Ivy.

\section{CELASTRUS - Bitiersweet}

Scandens. A native climber, with handsome, glossy foliage and large clusters of beautiful orange-crimson fruits, retained all Winter. Very bright in effect and charming for Winter house decoration.

\section{CLEMATIS Or VIRGIN'S BOWER}

of all the vines used for either shade or decoration, none can compare with the Clematis in its many and various forms. As a climber for the veranda, a screen for fences, for pillars, along garden walks, for training on walis or arbors, in masses or rockwork, it has no rival among the strong growing, blossoming plants. Their delight is in rich soil and a sunny situation, and they are perfectly hardy. They should be well mulched with rotten manure in Winter.

Jackmani. This variety is better known than any other, and still stands as one of the best. It is a strong grower, and produces a mass of intense violet-purple flowers four to six inches in diameter, from June until October.

Madame Edouard Andre. A distinct new variety, lately imported from France; very handsome red.

Paniculata, A great novelty from Japan. This variety of Clematis has proved to be one of the most desirable, useful and beautiful of hardy garden vines, a luxuriant grower, profuse bloomer, and possessing fine foliage.

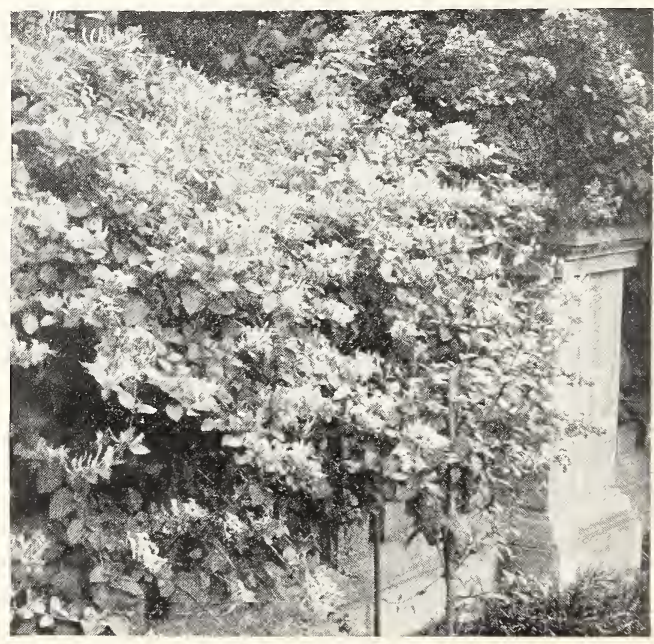

Hall's Japan Honeysuckle. 


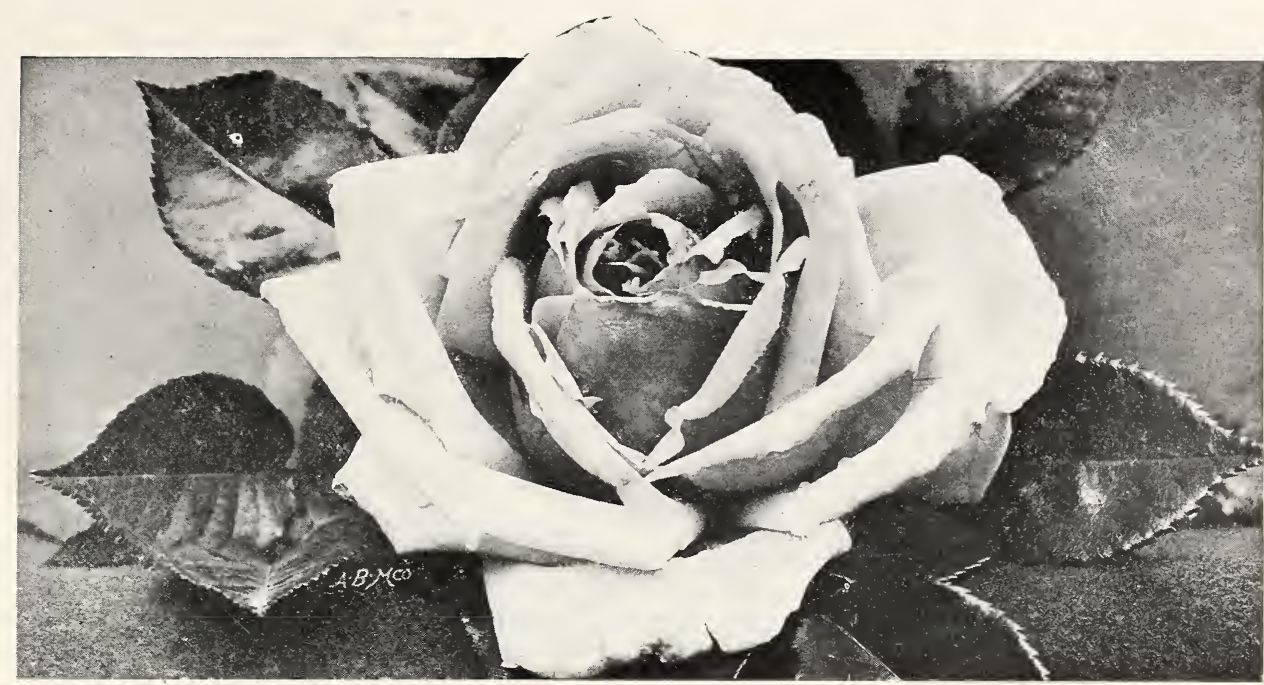

Sunburst Rose.

\section{Roses}

The Rose, "The Queen of Flowers," is justly one of the most popular in cultivation, and none gives better satisfaction to the lover of beautiful flowers when properly treated. To obtain richness and luxuriance of foliage, and well developed flowers, it must receive good cultivation.

To obtain the most satisfactory results they should be planted in well drained, deep, rich, loamy soil. If not naturally rich and deep, it should be made so by trenching or spading to the depth of two feet and incorporating with it well prepared compost of rotted manure. For Winter protection and to keep the soil in fine condition, an application of compost should be given them late in the Autumn, and spaded into the ground the following Spring.

Pruning is necessary to maintain a good shape, and to secure a good supply of young wood. This should be done in the Spring; the latter part of March is the best time. This is done by cutting off the previous year's growth to within three or four buds. The remaining buds will then throw out vigorous branches, and in due season produce a splendid bloom. This mode of pruning, however, is not applicable to Climbing Roses until the desired surface or space is covered.

\section{Hybrid Perpetual Roses}

Alfred Colomb. Dark red. Flowers are large, of fine globular form; a brilliant carmine-crimson. Raised from Jacqueminot.

Clio. A Rose of perfect form and finish, with broad, thick petals, high, full center, beautiful from pointed bud to fully opened flower. The color is a delicate satiny blush, with slightly deeper center.

Duke of Edinburgh. Brilliant crimson-scarlet, shaded with maroon.

Earl of Dufferin. Rich erimson-maroon with dark variety shading. The flowers are large, full, globe-shaped, thick-petaled, and very fragrant. Grows well and blooms freely, with many handsome buds in Autumn.

Eugene Furst. Velvety crimson, with darker shadings; large, full, shapely, fragrant.

Frau Karl Druschki. The finest white Hybrid Perpetual Rose, with large, full flowers of splendid form. One of the best.

Fisher Holmes. One of the choicest of Perpetual Roses. Bush is vigorous and produces freely of superb blossoms. Color brilliant carmine-crimson.

General Jacqueminot. Brilliant crimson, large and very fine: one of the handsomest and most showy Roses of this color. Beautiful in the bud; semi-double when full blown.

John Hopper. A fine and free blooming old sort, with large, full, handsome flowers of fresh bright rose. By far one of the best.
Margaret Dickson. Of magnificent form, white with pale flesh center; petals very large, shell-shaped and of great substance; fragrant; foliage very large, dark green; a vigorous grower.

Marshall P. Wilder. Raised from the seed of Gen. Jacqueminot. It is of vigorous growth, healthy foliage; flowers large, semi-globular, full, well formed; color cherry-carmine.

Mrs. John Laing. Satiny pink; entirely hardy, and blooms almost constantly throughout the season. Flowers of immense size, full and double, exceedingly fragrant, borne in great profusion on long, stiff stems. Buds long and pointed.

Prince Camille de Rohan. A velvety, blackish crimson Rose, of deep, distinct shade; the darkest Rose in cultivation; large, full and very handsome. Free bloomer.

Paul Neyron. The largest Rose in cultivation; sometimes called the Peony Rose; color bright, fresh, cerise-red.

Soleil d'Or. Robust, very vigorous; the flowers large, full and globular, measuring three and one-half inches across, and fragrant: color superb, varying from gold and orangeyellow to reddish gold.

Uhich Brummer. A Rose of beautiful form and finish, very striking from its color of brilliant cherry-crimson. The bush is vigorous, blooming continually in the open air, and displaying its superb glowing flowers on good stems. 


\section{Hardy Climbing Roses}

The perfect hardiness of this class of Roses, their strong growth and luxuriant foliage, adapt them for covering arbors, walls, trellises, and unsightly objects, which, together with their immense clusters of beautiful flowers commend them to all lovers of the beautiful. Require little pruning, except to thin out weak or dead branches.

Baltimore Belle. Pale blush, nearly white, very double; flowers in beautiful clusters; one of the best white climbers.

Climbing American Beauty. The flowers have the same form and color of the famous American Beauty-a rich, rosy crimson, and are delightfully fragrant.

Dorothy Perkins. This is a most beautiful new shell-pink Rose, having the same strong habit of growth as the Crimson Rambler. Very double, sweetly scented; absolutely hardy.

White Dorothy. Among Rambler Roses none has justly gained greater popularity than the beautiful pink Dorothy Perkins. The white Dorothy is a duplicate except in color, which is white.

Queen of the Prairies. Bright rosy red, striped with white; large and cupped; most beautiful and valuable of the class.

\section{The Rambler Roses}

Crimson. The foliage is exceptionally large and glossy, and when the plant is in bloom it looks like a mass of double crimson flowers.

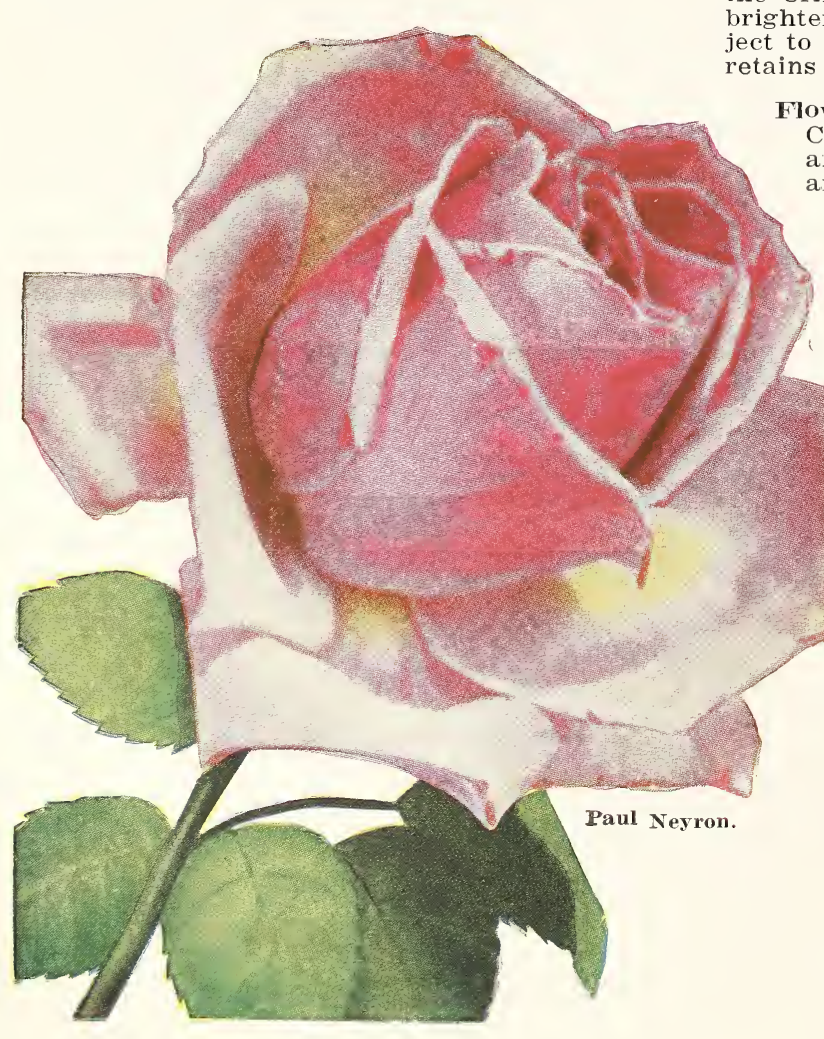

Excelsa. Brilliant scarlet, double flowers borne in immense trusses. A big improvement on the Crimson Rambler, in that its flowers are brighter in color and the foliage is not subject to mildew, being dark, glossy green, and tains its color all summer.

Nower of Fairfield (Perpetual Flowering Crimson Rambler). Its flowers, which are produced in marvelous profusion, are of a fine crimson color and more brilliant than the common Crimson Rambler. The orowth is vigorous, flowering freely and continuously throughout the season.

Goldfinch. An extra strong climbing Rose, with beautiful clusters of golden yellow flowers and handsome foliage. One of the best of the new yellow Climbing Roses, and much superior to the old Yellow Rambler.

Pink. Similar to others of this group, but with pink flower clusters.

Philadelphia. An improvement on the Crimson, with larger trusses of flowers which are perfectly double and more deeply colored. The color does not fade out, and the foliage is handsome at all times. Splendid for covering pergolas and porches.

White Rambler. In habit of growth. foliage, manner of blooming and shape of flower, this is identical with Crimson Rambler, differing in color.

Seven Sisters, or Greville. Vary in color from blush to crimson; flowers in large clusters; not hardy. 


\section{Everblooming Roses}

As a rule they are not entirely hardy in the northern states without protection, but the dwarfer kinds are readiı preserved by cutting down the entire plant in the Autumn to within six or eight inches of the ground and covering with long, strawy stable manure.

American Beauty. (H. T.) Although strictly a Hybrid 'Iea, this elegant Rose is usually classed among the Hybrid Perpetuals, owing to its vigorous growth. Very large, double, bright carmine-red. Fine for forcing.

General McArthur. (H. T.) The bud, when first opening, is the brightest crimson-scarlet, and the flower retains this perfect coloring until it drops its peta.s. Blooms continuously the whole season through, and gives fine stems for cutting.

Gruss an Teplitz. (H. T.) The color is dark, rich crimson, passing to velvety fiery red. Flowers large, full and sweet; blooms constantly, throwing up fresh buds and flowers the whole growing season.

Iillarney, White. (H. T.) In all respects similar to the Pink Killarney except in the color of its flowers, which are of a brilliant glistening white and borne on extra long, stiff stems. Particularly beautiful in bud state.

Killarney, Pink. (H. T.) Considered by many to be the most beautiful pink Rose ever introduced. It forms a strong, vigorous bush, with beautiful foliage, bearing a wondrous profusion of magnificent Roses all Summer.

Los Angeles. Produces a continuous succession of long-stemmed flowers of a luminous flame-pink, toned with coral and shaded with translucent gold at the base of petals; in richness of fragrance it equals in intensity the finest Marechal Niel. The buds are long and pointed.

\section{Baby Rambler Roses}

Baby Rambler. A Hybrid produced by crossing Crimson Rambler and the Gloire des Polyanthus; has the flowering quality of the latter, the color of the Crimson Rambler (clear, brilliant, ruby-rose). It blooms in clusters and is very continuous.

White Baby Rambler. The same as Baby Rambler, with white flowers.

\section{Austrian Roses}

This class flowers on extreme ends of wood of previous season's growth; very little prunins is therefore required.

Harrison's Yellow. Double, bright yellow; very showy and fine.

Persian Yellow. Deep bright yellow; small but handsome; double; a very early bloomer and much the finest hardy yellow Rose. This does the best when budded.

\section{Moss Roses}

This division of Roses embraces many of the most desirable qualities. The fine, mossy buds, large, fragrant flowers and perfect hardiness make it a universal favorite. It is ben fitted by an application of well-rotted manure, and a moderate pruning.

Admiral Dewey. Dark red; very vigorous grower; one of the very best.

Crested (Cristata). Distinct Rose, fine, curiously crested buds.

Glory of Mosses. Pale rose, very large, full and beautiful; very mossy and fragrant.

Salet. Bright rose, blush edges, large, profuse flowering. An elegant moss.

\section{Rosa Rugosa}

This Japanese Rose forms a sturdy bush, four to five feet high, covered with large, dark green, glossy foliage, crowned with terminal cluster: cf ten to twenty flowers, each three inches in diameter. Perfectly hardy. A valuable plant for the hardy border of shrubberies, its large, handsome, scarlet fruits being very ornamental all through the Autumn and early Winter months. It also makes a splendid hedge, its foliage being impervious to the attacks of insects of all kinds.

Agnes Emily Carman. Flowers large, semidouble, fine in the bud state; rich, deep crimson. A remarkably free bloomer, and continues in bloom a long time.

Blanc Double de Coubert. Purest paper-white; blooming in clusters of from five to ten flowers; double, very sweet. A strong, rampant grower, having the true Rugosa foliage. Flowers nearly five inches in diameter.

Charles Frederick Worth. A Hybrid Rugosa Rose of extremely strong growth, with attractive deep green foliage, more dense than other varieties. Flowers are deep crimson with carmine shadings.

New Century. A splendid Rose of the Rugosa type, with clear, flesh-pink flowers 3 to 4 inches across, perfectly full and double. Its perfumes remind one of the sweetbriers; one of the most constant bloomers of its class.

\section{Tree Roses}

The Tree Roses are grafted on hardy stems 4 to 5 feet high, and thus form tree shapes, When in full bloom they are very handsome and are becoming more popular every year as the demand for formal gardens grows. It is very necessary to have varieties which will lend themselves to the severe pruning and training necessary to produce the tree form, and in this shape we offer only the Hybrid Perpetual or hardy class, with flowers of white, pink, scarlet and crimson.

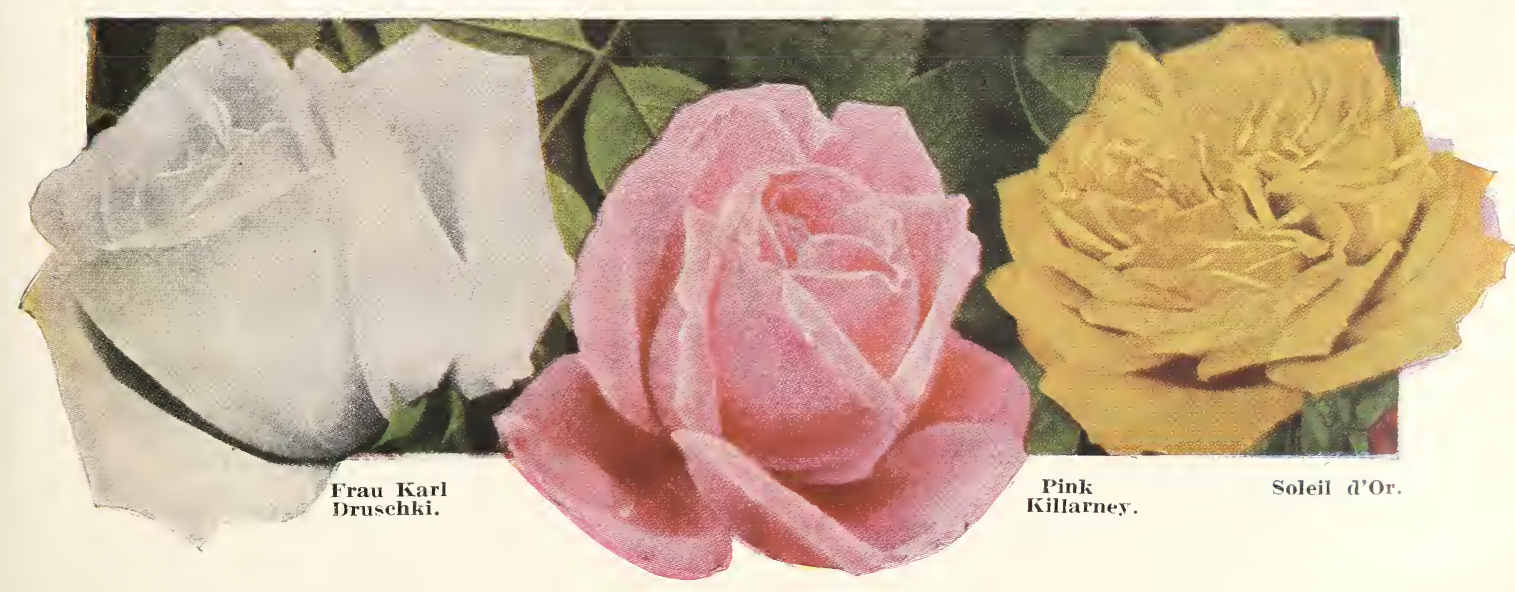




\section{Hardy Perennials}

These can be used to best advantage in groüs and beds on the lawn, as borders for drives, walks, or in front of shrubbery and in the garden. Some of the tall growing sorts may be planted in among the shrubbery with good effect. Most of the perennials can be planted in the Spring or Fall. Soil should be kept well fertilized. A light covering of coarse, strawy manure or something that will not pack is beneficial in Winter.

\section{ACHILLEA - Yarrow}

Ptarmica (The Pearl). Small double white flowers, very valuable for borders and gardens; a profuse bloomer.

\section{ANEMONE - Windflower}

One of the most showy of Autumn-blooming herbaceous plants. Blooms freely from August until cut down by frost. In light, somewhat moist, rich soil, the plants make a beautiful hardy border or bed. A slight covering of leaves or straw is sufficient protection in most severe Winters.

Japonica var. Prince Henry. Large, semidouble, deep red flowers on stems $1 \frac{1 / 2}{2}$ to $2 \frac{1}{2}$ feet high. August to October.

var. Queen Charlotte. Large, semi-double, flowers of silvery pink on stems 2 to 3 feet high.

var. rosea superba. Pale rose; plant grows 2 to 3 feet high; blooms from August to October.

\section{AQUILEGIA - Columbine}

Caerulea (Sky-blue Columbine). Flowers have large blue sepals with white petals.

\section{CHRYSAN'THEMUMS}

Golden Queen. Yellow. Hardy, large flowered. Victory. White.

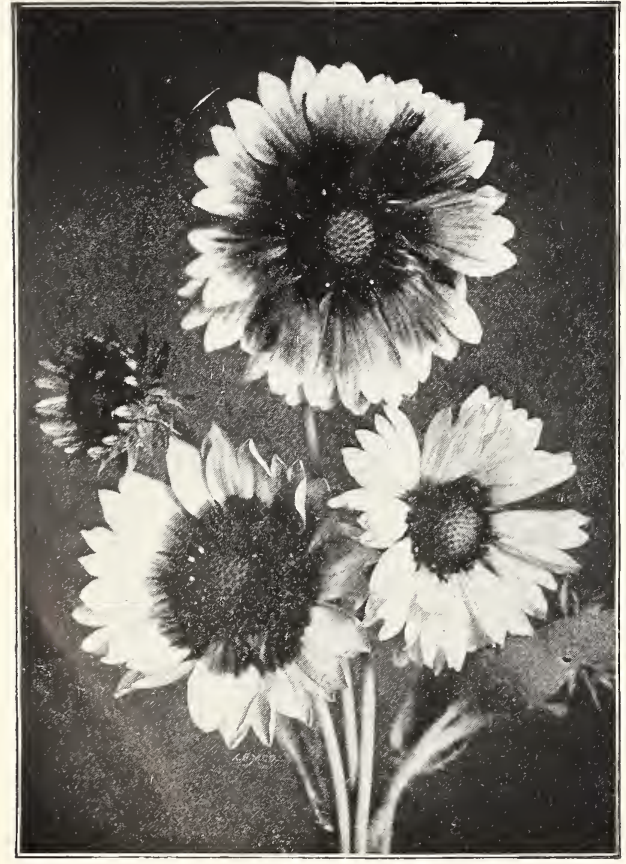

Gaillardia.

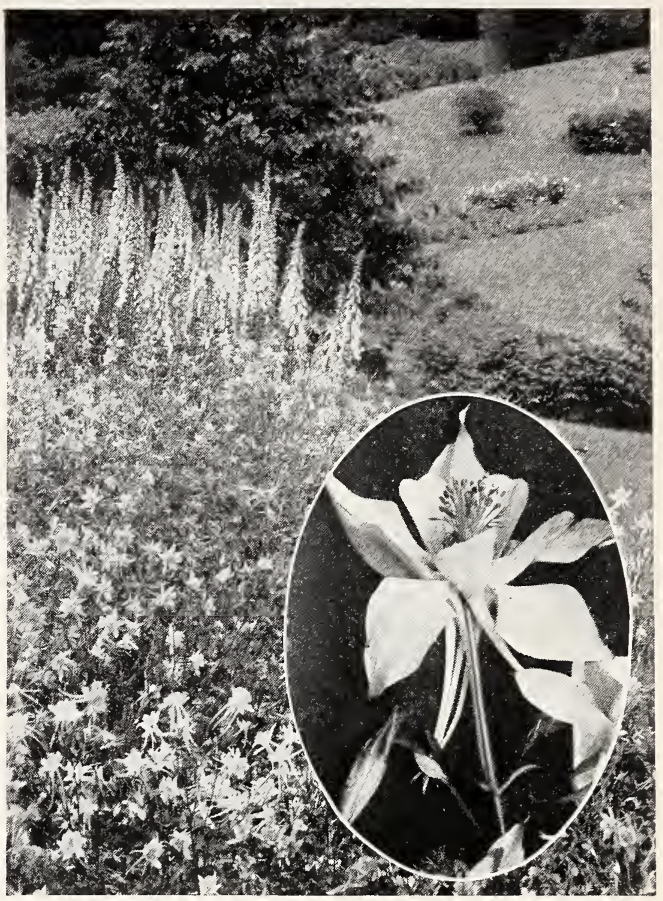

Aquilegia, With Digitalis in Background.

\section{COREOPSIS}

Grandiflora. Bright golden flowers on stems 2 to 3 feet long, in May and June. Flowers much larger and handsomer than the other variety.

Lanceolata. A beautiful hardy border plant that grows 15 to 18 inches high and produces its bright golden yellow flowers in great profusion the entire season. Beautiful masses and a favorite for cutting.

CONVALLARIA - Lily-of-the-Valley

Majalis, Large, luxuriant foliage; flowers small, bell-shaped, in pretty racemes, and very fragrant.

DIEIYTRA or DICENTRA - Bleeding Heart Spectabilis. The showy, heart-shaped flowers of rosy crimson and silvery white of this plant are borne on a graceful, drooping raceme a foot or more in length. It is superb for the garden, and perfectly hardy everywhere. Flowers in April and May.

\section{DELPHINIUM - Larkspur}

There is no hardy perennial more easily grown than the Delphinium. It revels in full sunshine and a deeply worked, rich soil, with plenty of water during dry spells.

Formosum. The old favorite dark blue variety, grows from three to four feet high, very vigorous and free flowering; one of the best.

\section{DIANTHUS - Pink}

Barbatus (Sweet William). Among the most esteemed and valuable of hardy plants, producing flowers of a great variety of colors.

\section{DIGITALIS - Foxglove}

Ornamental plants, bearing spikes of long, tubular flowers. Very popular and much employed in gardens.

Purpurea, Flowers purple varying to white, in long terminal spikes; 2 to 3 feet. June to August. 


\section{FUNKIA - Day Lily}

The Funkias all make handsome, showy plants with beautiful, broad, ovate leaves, and large, lily-like, fragrant flowers in large clusters. They like to grow in moist, shaded places and form clumps 12 to 20 inches high. In bloom from July to September.

Undulata variegata. One of the most popular border plants cultivated; very striking foliage, green all splashed with white.

Lanceolara (Day Lily). Handsome foliage of deep glossy green color, free blooming habit Will do first-class close to buildings or under shade of trees.

\section{GAILLARDIA - Blanket Flower}

A genus of very ornamental hardy plants. Flowers yellow or purple, 2 inches across, single on naked stems. Very showy. Early summer until Autumn.

HELIANTHUS - Perennial Sunflower

Mollis grandiflora (Sunflower). Light lemonyellow, large, single. Foliage quite hairy.

\section{HIBISCUS - Mallow}

Moscheutos (Swamp Rose Mallow). Large purplish pink or nearly white flowers. Grows 4 to 5 feet high and blooms in August and September. One of the most gorgeous of perennials and attracts great attention wherever grown.

\section{HOLLYHOCKS}

The Hollyhock is an old garden favorite, full of sentiment and association with a distant past. It is a plant of strong, vigurous growth and noble aspect, with elegant camellialike flowers that form perfect rosettes.

Single Mixed. We have a splendid assortment of these majestic old-fashioned flowers which everyone knows and loves. They grow 4 to 6 feet tall-higher at times-and bloom from July to August.

We offer a fine collection of double sorts in four distinct colors: Crimson, Yellow, Pink and White.

\section{HARDY PHLOXES}

These are justly esteemed as the finest of herbaceous plants. They are of dwarf habit, perfectly hardy, of very easy culture, and yield a profusion of bright, showy bloom. They are hardly ecualed by any other hardy plant for the decoration of the garden.

Athis. Light salmon-rose; tallest of all.

Bridesmaid. Pure white with large crimson center.

Eclaireur. Salmon-scarlet, bright crimson eye. The Pearl. Tall, white, late.

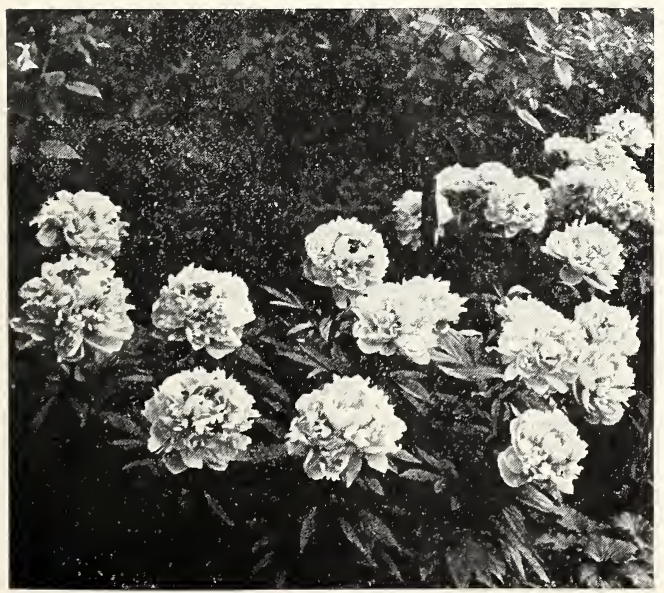

Peony Border.

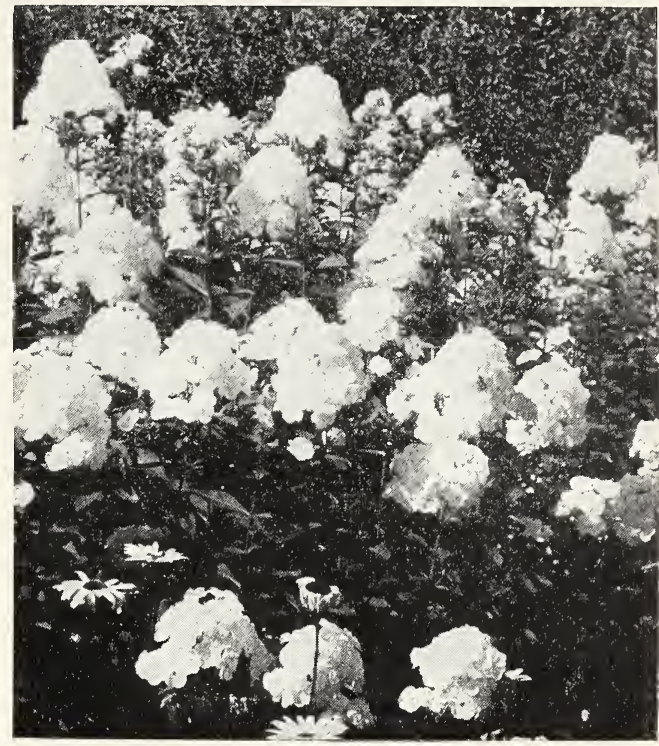

Hardy Phlox.

PAPAVER - Poppy

Showy perennials with large flowers, of rich and striking colors.

Orientale (Oriental Poppy). Deep scarlet; large; very showy; 18 inches. June.

\section{PAEONIA - Peony}

Peonies have always held an important place among hardy plants, and with the wonderful improvement made during the recent years, have established themselves among the leaders for popular favor. They are the nearest rivaling the Rose in brilliancy of color and perfection of bloom. They are hardier and more easily cultivated than their rival, and once planted, all is done, and each succeeding year adds to their size and beauty.

Anemoneflora. Dark red.

Alexandrina. Pink.

Baron Rothschild. Silvery rose center, bright rose.

Bertha d'Hour. Deep rose.

Delachei. Dark red.

Delicatissima. Light rose color.

Duke of Wellington. Sulphur-yellow.

Festiva Alba. Fine, large, pure white flowers.

Festiva Maxima. Extra large, white center, petals tipped carmine.

Mad. Lois. Dark purple-violet.

\section{TRITOMA - Red Hot Poker}

These are tall and striking plants of much beauty when well placed and properly grown. The great spikes of red flowers, sent up from the center of a broad circle of green leaves have guite a rich and tropical appearance. Give some protection in cold climates.

Pfitzeri. Spikes a foot or more in length, thickly set with orange-scarlet to salmon flowers.

Uvaria (Kniphofia Aloides), Dazzling scarletvermilion spikes of the sky-rocket order.

var. grandiflora. A variety with larger flowers on longer spikes.

\section{VERONICA - SpeedweII}

Amethystina. Amethyst-blue flowers in July and August. 2 feet.

Longifolia subsessilis. A pretty species with blue flowers, produced on spikes a foot long, continuing in bloom the entire summer and Fall. 


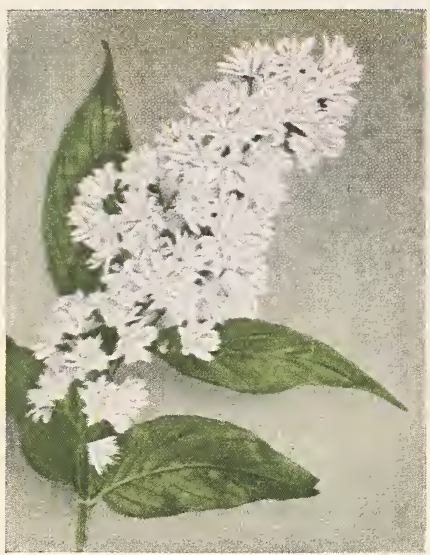

Deutzia, Pride of Rochester.

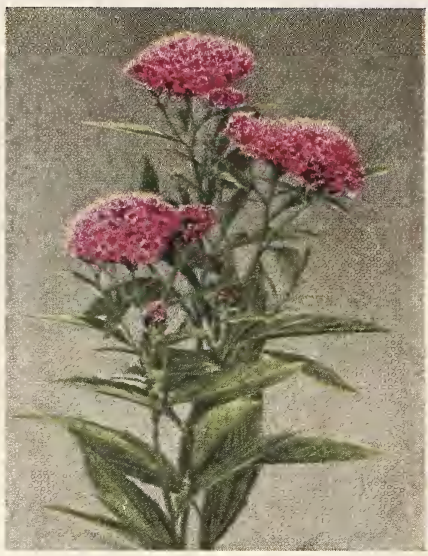

Spirea, Anthony Waterer.

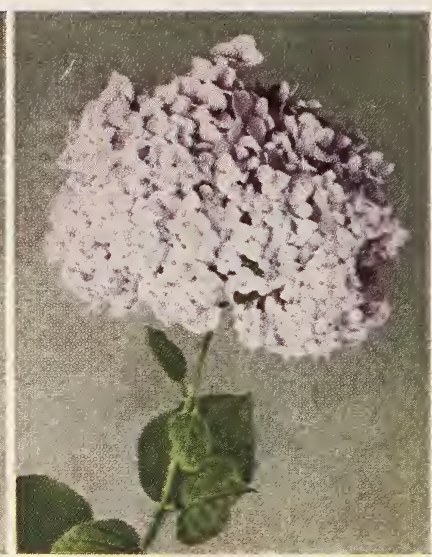

Hydrangea Arborescens.

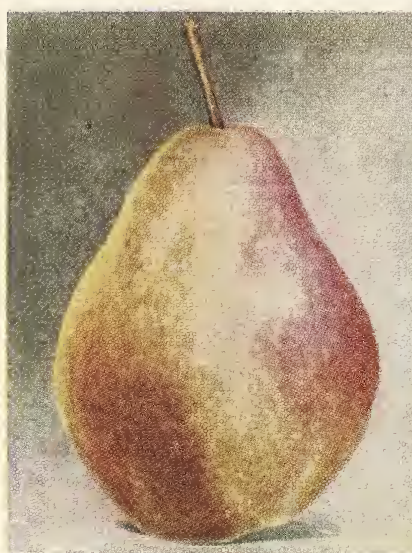

Kieffer Pear.

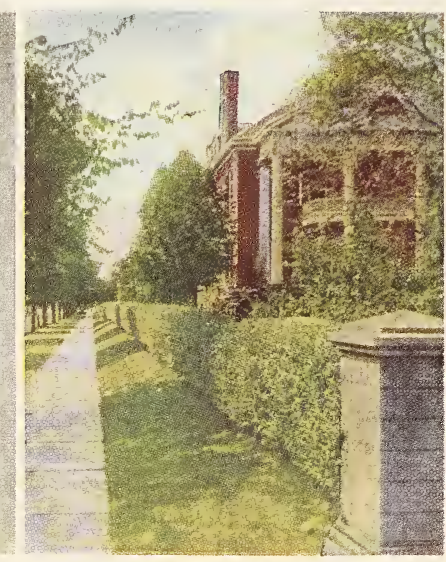

California Privet Hedge.

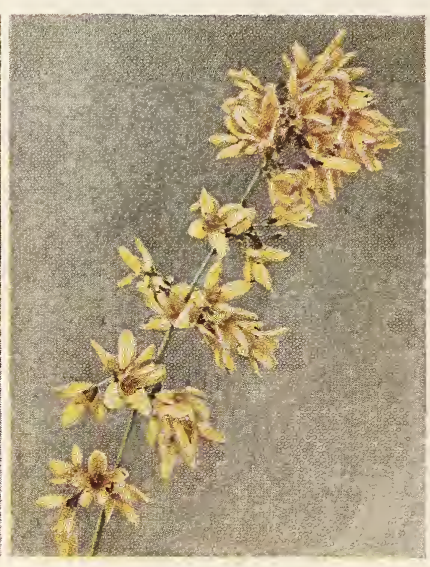

Forsythia.

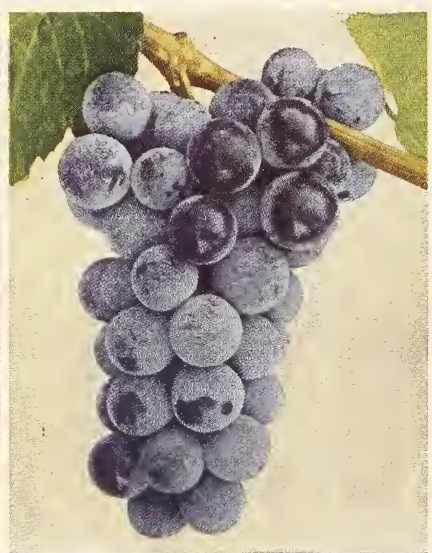

Concord Grapes.

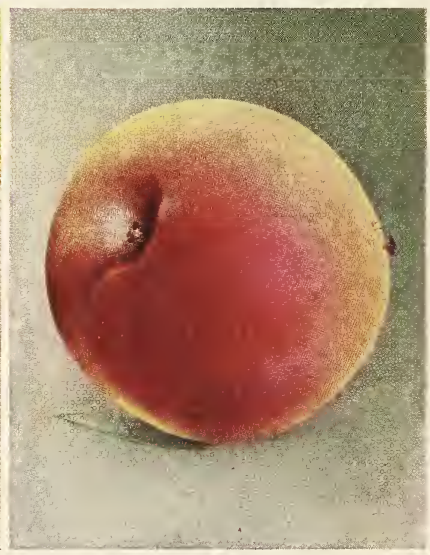

Rochester Peach.

\section{Cutler \& Downing Nurseries}

FRUIT TREES AND PLANTS -:- ORNAMENTALS 